\title{
Effects of Leaf Potassium Content on Growth Dynamics of Muskmelon and Developing a Coupling Model of Nitrogen and Potassium
}

\author{
Xiaofeng Yang ${ }^{1}$ \\ College of Tropical Crop, Hainan University, No. 58, Renmin Avenue, Haikou, \\ Hainan Province, 570228, China; and Sanya Science and Technology Academy \\ for Crop Winter Multiplication, No. 192, Jiyang Road, Sanya, Hainan Province, \\ 572000, China
}

\author{
Lianzhu Chen', Ming Cao, and Xuebin Zhang \\ Sanya Science and Technology Academy for Crop Winter Multiplication, No. \\ 192, Jiyang Road, Sanya, Hainan Province, 572000, China
}

\author{
Shaopeng $\mathbf{L i}^{2}$ \\ College of Horticulture, Hainan University, No. 58, Renmin Avenue, Haikou, \\ Hainan Province, 570228, China
}

Additional index words. muskmelon, nitrogen and potassium coupling, leaf photosynthetic rate, leaf area index, partitioning index, model

\begin{abstract}
Nitrogen and potassium are two crucial nutrient elements that affect the yield and quality of crops. The aim of this study was to quantify the impacts of potassium on growth dynamics and quality of muskmelon, so as to optimize potassium management for muskmelon in a plastic greenhouse, and develop a coupling model of nitrogen and potassium. For this purpose, four experiments (two experiments with different levels of potassium treatment and planting dates, and the other two experiments with different ratios of nitrogen and potassium, and planting dates) on muskmelon (Cucumis melo L. 'Nanhaimi' and 'Xizhoumi 25') were conducted in a plastic greenhouse located at Sanya from Jan. 2014 to Sept. 2015. The quantitative relationship between leaf potassium content and growth dynamics and yield of muskmelon was determined and incorporated into a photosynthesis-driven crop growth model (SUCROS). Independent experimental data were used to validate the model. The critical leaf potassium content at the flowering stage for muskmelon 'Nanhaimi' and 'Xizhoumi 25' were 55.0 and $46.0 \mathrm{mg} \cdot \mathrm{g}^{-1}$. The result showed that the coefficient of determination $\left(r^{2}\right)$ between the predicted and measured values of leaf area index (LAI), direct weight of shoot (DWSH), direct weight of stem (DWST), dry weight of leaf (DWL), dry weight of fruit (DWF), fresh weight of fruit (FWF), soluble sugar content (SU), soluble protein content (PR), vitamin C (Vc), and soluble solids content $(\mathrm{SO})$ of potassium model were $0.93,0.98,0.83,0.96,0.98,0.99,0.94,0.94$, $0.89,0.85$, and 0.90 , respectively; and the relative root-mean-squared error (rRMSE) were $10.8 \%, 19.6 \%, 30.3 \%, 21.1 \%, 11.9 \%, 17.2 \%, 13.9 \%, 27.8 \%, 20.6 \%$, and $10.1 \%$, respectively. The two ways of nitrogen and potassium coupling (multiplicative coupling and minimum coupling) were compared, and the multiplicative coupling was used in model development finally. The $r^{2}$ between the predicted and measured values of LAI, DWSH, DWST, DWL, DWF, FWF, SU, PR, Vc, and SO of nitrogen and potassium coupling model were $0.78,0.91$, $0.93,0.94,0.83,0.89,0.92,0.95,0.91$, and 0.93 , respectively; and their rRMSE were $9.2 \%$, $12.4 \%, 11.8 \%, 43.2 \%, 6.6 \%, 7.2 \%, 6.85 \%, 4.98 \%, 6.61 \%$, and $4.35 \%$, respectively. The models could be used for the optimization of potassium, nitrogen, and potassium coupling management for muskmelon production in a plastic greenhouse.
\end{abstract}

The growth and development of vegetables require a large amount of nitrogen and potassium (Balliu and Bro, 2002; Hebbar et al., 2004). Potassium application and its

Received for publication 27 Feb. 2019. Accepted for publication 28 Apr. 2019.

This work was supported by National Natural Science Foundation of China (31260492), National Science and Technology Supporting Project of China (2014BAD05B04).

${ }^{1}$ These authors contributed equally to this work.

${ }^{2}$ Corresponding author. E-mail: lisp555@126.com.

absorption and assimilation of nitrogen in vegetables and improve the agricultural utilization efficiency of nitrogen (Ardjasa et al., 2002; Mohammad and Naseem, 2006; Zhu and Chen, 2002).

Muskmelon is one of the most important economic crops in protective cultivation in Hainan, and its cultivation techniques are being increasingly improved. There is no doubt that fertilization management is still the key to improve its yield and quality. Fully developing nitrogen and potassium coupling model is helpful to better understand the effect of fertilization on growth and quality of muskmelon.

As an important foundation of modern agricultural expert management systems, the crop growth dynamics model has become a hot research topic in recent years. At present, the models applying to horticultural crops are mainly focused on the growth mechanism. However, it is deficient to fertilization management. N Expert (Fink and Scharpf, 1993) and N ABLE models (Greenwood, 2001) are the two existing decision models for nitrogen application in vegetables. The $\mathrm{N}$ ABLE model has been widely used in Europe, and developed to many other nitrogen management models for various vegetables such as WELL N model (Rahn et al., 2001) and EU-Rotate N model (Rahn et al., 2010). The EU-Rotate $\mathrm{N}$ model has been widely used to simulate the growth of vegetables under different water and nitrogen conditions, and it has been verified by a large number of data of field and greenhouse vegetables. A complete database of vegetable parameters has been established (Nendel, 2009; Soto et al., 2014; Suárez-Rey et al., 2016), but these models have never been involved in nitrogen and potassium coupling optimize for muskmelon.

The objective of this study was to develop a dynamics model to quantitatively investigate the impacts of potassium on growth dynamics and yield to facilitate the optimization of potassium management for muskmelon production in plastic greenhouses, and develop a coupling model of nitrogen and potassium. For this purpose, four experiments (two experiments with different levels of potassium treatment and planting dates, and the other two experiments with different ratios of nitrogen and potassium, and planting dates) were carried out in a plastic greenhouse to collect data for model development and validation.

\section{Materials and Methods}

balanced relative ratio to nitrogen are the most important for the crop productivity (Awais et al., 2017). Most previous studies showed that the interaction of nitrogen and potassium was positive, and appropriate proportion of nitrogen and potassium could improve the yield and quality of crops, such as improving the fruit number, fruit weight, yield, vitamin $\mathrm{C}$, soluble sugar, and organic acid content of fruit of tomato (Belay et al., 2002; Chen et al., 2004; Ju et al., 2004; Wang et al., 2007). Furthermore, increasing the supply level of potassium could promote the
Plant materials and experiment design. Experiments of different levels of potassium fertilizer and planting dates were conducted in a plastic greenhouse of Sanya Science and Technology Academy for Crop Winter Multiplication (long. $18^{\circ} 15^{\prime} \mathrm{N}$, lat. $109^{\circ} 30^{\prime} \mathrm{E}$ ). The orientation of the plastic greenhouse was from south to north direction. The length, span, and height of the plastic greenhouse were $36,4.6$, and $3.2 \mathrm{~m}$, respectively. In each experiment, muskmelon seedlings were planted in soilless substrate and irrigated by 
Table 1. Available potassium during the experimental season.

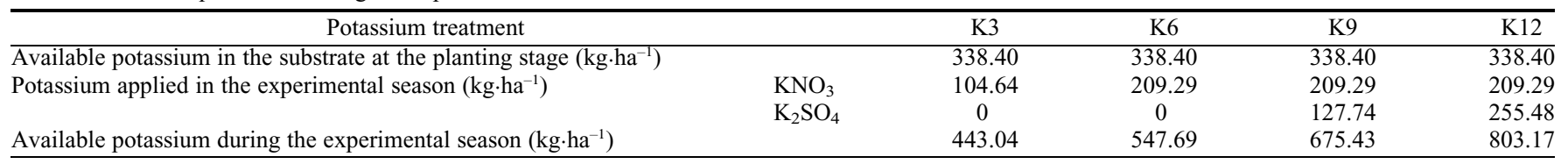

Table 2. Available nitrogen and potassium during the experimental season.

\begin{tabular}{|c|c|c|c|c|c|c|c|c|c|}
\hline & $\mathrm{N} 7 \mathrm{~K} 3$ & N7K6 & N7K9 & N7K12 & N13K3 & N13K6 & N13K9 & N13K12 \\
\hline \multirow[t]{2}{*}{ Nitrogen applied in the experimental season $\left(\mathrm{kg} \cdot \mathrm{ha}^{-1}\right)$} & $\mathrm{Ca}\left(\mathrm{NO}_{3}\right)_{2} \cdot 4 \mathrm{H}_{2} \mathrm{O}$ & 87.55 & 87.55 & 87.55 & 87.55 & 87.55 & 87.55 & 87.55 & 87.55 \\
\hline & $\mathrm{NaN}$ & 0 & 0 & 0 & 0 & 82.44 & 82.44 & 82.44 & 82.44 \\
\hline $\begin{array}{l}\text { Available potassium in the substrate at the planting stage } \\
\left(\mathrm{kg} \cdot \mathrm{ha}^{-1}\right)\end{array}$ & & 457.00 & 457.00 & 457.00 & 457.00 & 457.00 & 457.00 & 457.00 & 457.00 \\
\hline Potassium applied in the experimental season $\left(\mathrm{kg} \cdot \mathrm{ha}^{-1}\right)$ & $\mathrm{K}_{2} \mathrm{SO}_{4}$ & 127.74 & 255.48 & 383.20 & 510.96 & 127.74 & 255.48 & 383.20 & 510.96 \\
\hline
\end{tabular}
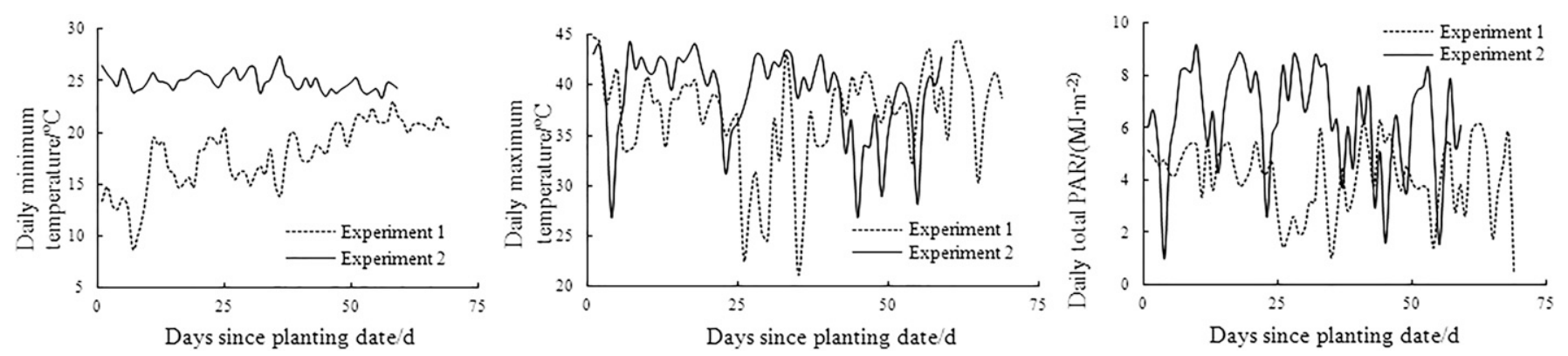

Fig. 1. Daily maximum temperature, minimum temperature, and daily total photosynthetically active radiation $(P A R)$ of potassium experiment.

drip fertigation. Cultivation substrate was made of the mixture of coconut chaff and river sand with a ratio of $2: 1$. The $\mathrm{pH}$, available nitrogen, available phosphorus, available potassium, and bulk density of the substrate were $6.63 \pm 0.2,13.5 \pm 0.2 \mathrm{mg} \cdot \mathrm{kg}^{-1}$, $86 \pm 16 \mathrm{mg} \cdot \mathrm{kg}^{-1}, 141 \pm 23 \mathrm{mg} \cdot \mathrm{kg}^{-1}$, and $(0.8 \pm$ $0.1) \cdot 10^{6} \mathrm{mg} \cdot \mathrm{m}^{-3}$, respectively.

Four levels of potassium concentration treatment (K3: 3, K6: 6, K9: 9, and K12: 12 $\mathrm{mmol} \cdot \mathrm{L}^{-1}$ ) were used in each experiment based on the Yamazaki muskmelon nutrient solution concentration. From planting date to the early stage of fruit development, 0.5 times of nutrient solution with $0.5 \mathrm{~L}$ was used once a day (0800-1100 HR) for each plant. From early stage of fruit development to last stage of fruit development, one time of the nutrient solution with $1.0 \mathrm{~L}$ was used twice a day (0800-1100 HR and 1500-1800 HR) for each plant. From last stage of fruit development to the harvest date (fruit ripening process), 0.5 times of nutrient solution with $0.5 \mathrm{~L}$ was used once a day (0800-1100 HR) for each plant.

The planting density was 2.2 plant $/ \mathrm{m}^{2}$. The plot of an area of $16.5 \mathrm{~m}^{2}$ for each potassium treatment with three replicates was arranged in a randomized block design. The available potassium during the experimental season $\left(\mathrm{K}_{\mathrm{s}}, \mathrm{kg} \cdot \mathrm{ha}^{-1}\right)$ was shown in Table 1. Two experiments were carried out according to different planting dates.

Expt. 1 was used to model development, and the planting date was 13 Jan. 2014; the

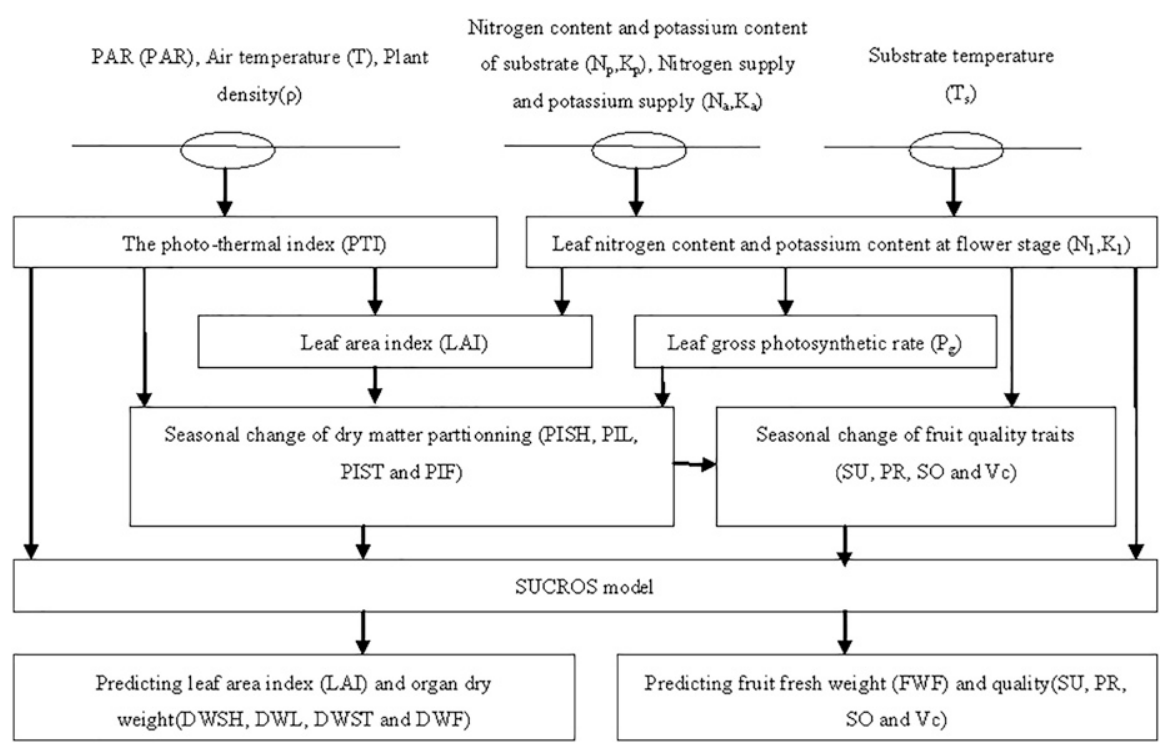

Fig. 2. Conceptual framework of the model developed in our study. DWF $=$ dry weight of fruit; $D W L=$ dry weight of leaf; DWSH = direct weight of shoot; DWST = direct weight of stem; PAR = photosynthetically active radiation; PIF = partitioning index of fruit; PIL = partitioning index of leaf; $\mathrm{PISH}=$ partitioning index of shoot; $\mathrm{PIST}=$ partitioning index of stem; $\mathrm{PR}=$ soluble protein content; $\mathrm{SO}$ $=$ soluble solids content; $\mathrm{SU}=$ soluble sugar content; $\mathrm{Vc}=$ vitamin $\mathrm{C}$.

harvest date was 29 Mar. 2014. The cultivars were Nanhaimi and Xizhoumi 25.

Expt. 2 was used for model validation, and the planting date was 17 July 2014; the harvest date was 25 Sept. 2014. The cultivars were Nanhaimi and Xizhoumi 25.
There were eight treatments of different ratios of nitrogen and potassium (N7K3, N7K6, N7K9, N7K12, N13K3, N13K6, N13K9, and N13K12) based on the Yamazaki muskmelon nutrient solution concentration. The nutrient solution and cultivation management 
during the experimental season was the same as the potassium fertilizer experiment. The $\mathrm{pH}$, available nitrogen, available phosphorus, available potassium, and bulk density of the

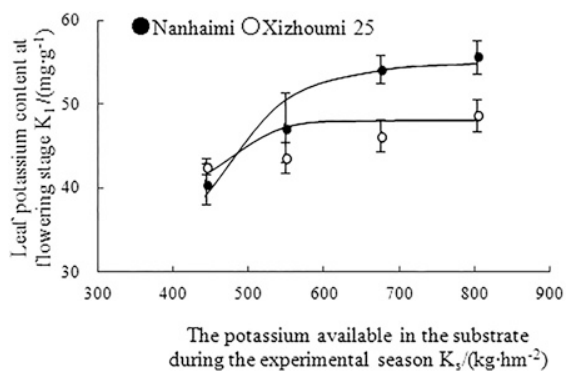

Fig. 3. Relationship between the leaf potassium content at flowering stage $\left(\mathrm{K}_{1}\right)$ and the available potassium during the experimental season $\left(\mathrm{K}_{\mathrm{s}}\right)$ of Expt. 1.

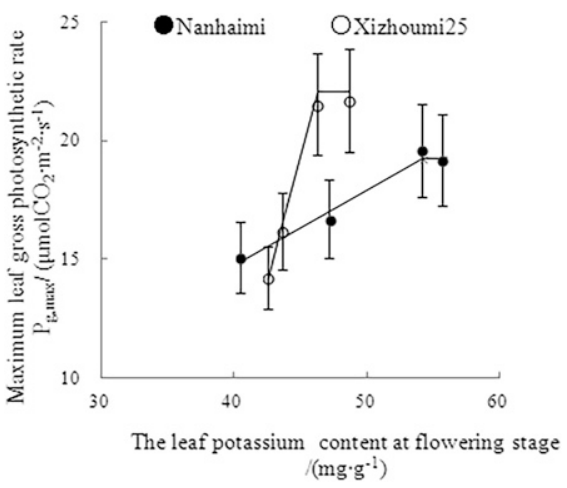

Fig. 4. Relationship between photosynthetically active radiation-saturated leaf gross photosynthetic rate $\left(\mathrm{P}_{\mathrm{g} \text {,max }}\right)$ and the leaf potassium content at flowering stage $\left(\mathrm{K}_{1}\right)$. substrate were $6.88 \pm 0.1,11.2 \pm 0.3 \mathrm{mg} \cdot \mathrm{kg}^{-1}$ $80.4 \pm 11 \mathrm{mg} \cdot \mathrm{kg}^{-1}, 195.3 \pm 18 \mathrm{mg} \cdot \mathrm{kg}^{-1}$, and $(0.78 \pm 0.08) \cdot 10^{6} \mathrm{mg} \cdot \mathrm{m}^{-3}$, respectively. The available nitrogen and potassium during the experimental season are shown in Table 2.

Expt. 3 was used to model development, and the planting date was 7 Jan. 2015; the harvest date was 23 Mar. 2015. The cultivars were Nanhaimi and Xizhoumi 25.

Expt. 4 was used for model validation, and the planting date was 11 July 2015; and the harvest date was 19 Sept. 2015.The cultivars were Nanhaimi and Xizhoumi 25.

Measurements. In each experiment, the light intensity, air temperature at a height of $1.5 \mathrm{~m}$ aboveground (ZDR-24; ZEDR Inc., Hangzhou, Zhejiang, China), and substrate temperature (HE-02New; ZEDR Inc.) inside the plastic greenhouse were monitored automatically every $10 \mathrm{~s}$, and the 30-min averaged data were recorded using a data logger. The light intensity (lx) readings were converted to photosynthetic active radiation $\left(P A R ; \mathrm{mmol} \cdot \mathrm{m}^{-2} \cdot \mathrm{s}^{-1}\right)$ by using the following approximation: $54 \mathrm{~lx}=1 \mathrm{mmol} \cdot \mathrm{m}^{-2} \cdot \mathrm{s}^{-1}$ for sunlight as recommended by Burnell et al. (2014). Daily maximum temperature, minimum temperature, and daily total $P A R$ of potassium experiments are shown in Fig. 1.

In each experiment, one plant per plot (three plants in total for each treatment) was randomly selected for destructive growth dynamics measurements once every $15 \mathrm{~d}$ since the planting date. The measurements of leaf included the length and area of each leaf node (LI-3000A; LI-COR Inc., Lincoln, NE). The leaf length was used to estimate leaf area and LAI. Partitioning of dry matter was modeled in two steps: first, between the root and the shoot, and then among organs within the shoot. Within-shoot organs included leaf, stem, and fruit, which needed measurement of their fresh weight and dry weight (drying 15 min under $105^{\circ} \mathrm{C}$, continuous drying until the weight was unchanging under $75^{\circ} \mathrm{C}$ ). Available nitrogen, phosphorus, and potassium in substrate at the planting stage and leaf total nitrogen and potassium content at flowering stage were measured in this study. Total nitrogen and total potassium was measured by the Kjeldahl method and flame photometric method, respectively (Lu, 1999). After flowering, fruit quality traits (SU, PR, Vc, and SO) were determined using the anthrone colorimetric method, the Coomassie brilliant blue G250 method, the 2, 6-dichlorindophenol titration method, and the handheld glucose meter, respectively $(\mathrm{Li}, 2000)$.

Model structure. The overall model structure is shown in Fig. 2 (for the nitrogen and potassium coupling model). The data of Expt. 3 were used for model development, and data of Expt. 4 were used for model validation. The inputs of the model were environmental information (PAR at a $1.5-\mathrm{m}$ height aboveground, air and substrate temperature in plastic greenhouse), available nitrogen and available potassium during the experimental season (the sum of the available nitrogen and potassium in the substrate at the planting stage, and the nitrogen and potassium applied in the experimental season), and crop information (planting date and planting density). Using data of Expt. 3, the following six steps were taken to develop the model: 1) the photothermal index (PTI) (defined as the daily average normalized thermal time multiplied by the daily total $P A R$ intercepted by canopy) was calculated according to Xu et al. (2010) using daily total $P A R$, hourly air

Table 3. List of parameter values determined by measured data in Expt. 1.

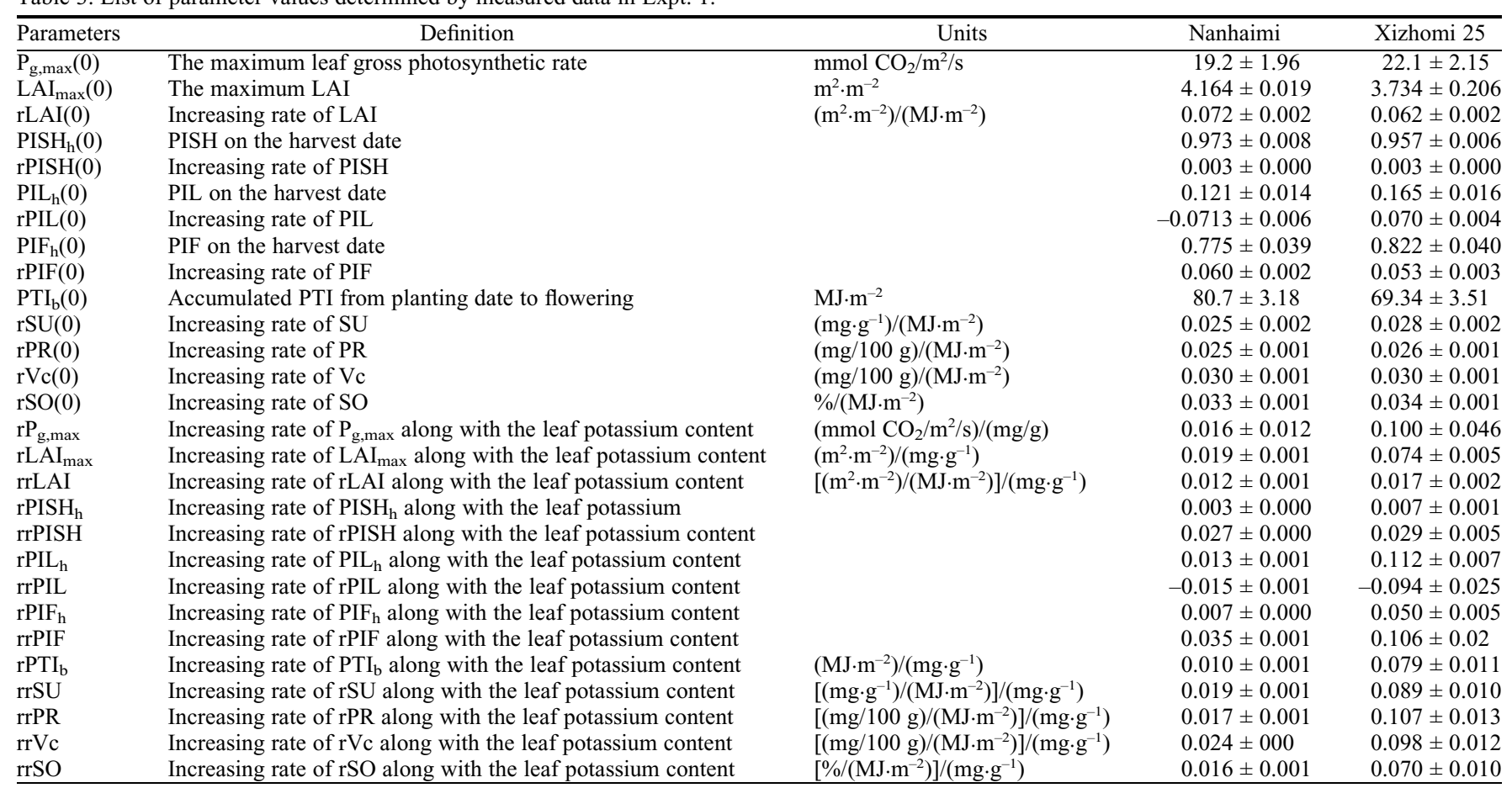

$\mathrm{LAI}=$ leaf area index; $\mathrm{SU}=$ soluble sugar content $\mathrm{PR}=$ soluble protein content; $\mathrm{Vc}=$ vitamin $\mathrm{C}$ content; $\mathrm{SO}=$ soluble solids content; $\mathrm{PISH}=$ partitioning index of shoot; PIL = partitioning index of leaf; PIF = partitioning index of fruit. 
temperature at $1.5 \mathrm{~m}$ aboveground and planting density; 2) the nitrogen and potassium indicator (leaf nitrogen content and potassium content at flowering stage) was calculated according to available nitrogen and potassium content during the experimental season and the average temperature of substrate; 3) the leaf gross photosynthetic rate $\left(\mathrm{P}_{\mathrm{g}}\right)$ was simulated using negative exponential equation and the impacts of leaf nitrogen content and potassium content on $\mathrm{P}_{\mathrm{g}, \max }$ (the $P A R$-saturated leaf gross photosynthetic rate) were determined by curve fitting the experimental data; 4) the LAI was determined as functions of PTI by curve fitting the experimental data and the impacts of nitrogen and potassium on $\mathrm{LAI}_{\max }$ and $\mathrm{rLAI}$ (the maximum value and the increasing rate of LAI) was quantified by curve fitting the experimental data; 5) the seasonal change of partitioning index of dry matter [partitioning index of shoot, leaf, stem, and fruit (PISH, PIL, PIST, and PIF, respectively)] and fruit quality traits ( $\mathrm{SU}, \mathrm{PR}, \mathrm{Vc}$, and $\mathrm{SO}$ ) were determined as functions of PTI by curve fitting the experimental data and the impacts of leaf nitrogen and potassium content on these parameters were determined by curve fitting the experimental data; 6) the LAI, organ dry weight (DWSH, DWL, DWST, and DWF), FWF, and quality (SU, PR, Vc, and SO) were estimated by integrating the simulation of $\mathrm{P}_{\mathrm{g}}$, LAI, seasonal changes of dry matter partitioning, and fruit quality traits into the existing SUCROS (Goudriaan and Van Laar, 1994). Details of this model approach and main equations are outlined as follows.

Determination of the PTI. Temperature and radiation are the main climate factors affecting the growth dynamics and yield of muskmelon. The accumulated PTI ( $\mathrm{PTI}_{\text {sum }}$ ) was used to describe the dynamics of growth and yield.

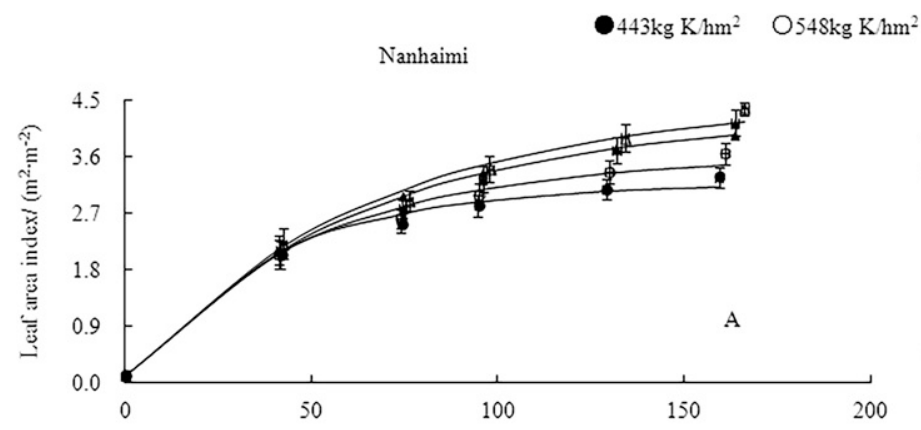

$\Delta 675 \mathrm{~kg} \mathrm{Khm}^{2} \triangle 803 \mathrm{~kg} \mathrm{Khm}$
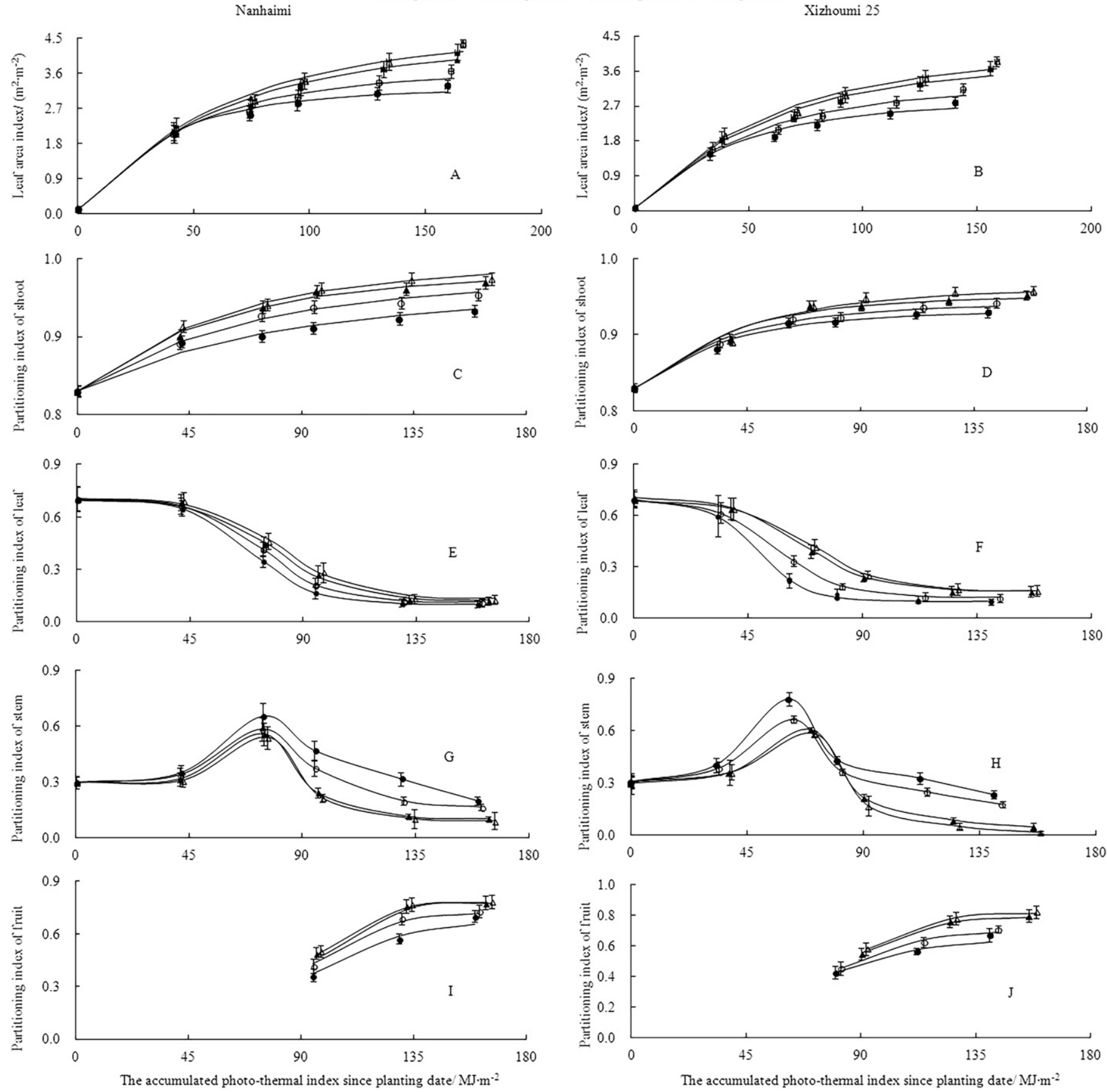

Fig. 5. Relationship between leaf area index (LAI), partitioning index of shoot (PISH), partitioning index of leaf (PIL), partitioning index of stem (PIST), partitioning index of fruit (PIF), and the accumulated photothermal index since planting date ( $\mathrm{PTI}_{\text {sum }}$ ) under different potassium supply conditions. 
According to $\mathrm{Xu}$ et al. (2010), the PTI was calculated as follows (Eqs. [1] and [2]):

$$
\operatorname{DPTI}(\mathrm{j})=\left(\frac{1}{48} \sum_{\mathrm{i}=1}^{\mathrm{j}} \mathrm{TT}(\mathrm{i}, \mathrm{j})\right) \times P A R_{\text {int }}(\mathrm{j})
$$

$$
\mathrm{PTI}_{\text {sum }}=\sum \operatorname{DPTI}(\mathrm{j}) \text {, }
$$

where DPTI(j) $\left(\mathrm{MJ} \cdot \mathrm{m}^{-2} \cdot \mathrm{d}^{-1}\right)$ is the PTI on day $\mathrm{j}, P A R_{\text {int }}(\mathrm{j})\left(\mathrm{MJ} \cdot \mathrm{m}^{-2} \cdot \mathrm{d}^{-1}\right)$ is the daily total $P A R$ intercepted by crop canopy on day $\mathrm{j}$, TT( $\mathrm{i}, \mathrm{j})$ is the half-hourly based normalized thermal time on day $\mathrm{j}$, and $\mathrm{PTI}_{\text {sum }}\left(\mathrm{MJ} \cdot \mathrm{m}^{-2}\right)$ is the accumulated PTI. $P A R_{\text {int }}(\mathrm{j})$ and TT $(\mathrm{i}, \mathrm{j})$ were calculated according to $\mathrm{Xu}$ et al. (2010).

Determination of potassium indicator. In our former nitrogen fertilizer model study of muskmelon, it was found that the growth and quality of muskmelon was not only linear with the nitrogen content at flowering stage, but also linear with the potassium content at flowering stage. Therefore, potassium content at flowering stage was used in our study to quantify the effect of potassium on the growth process and yield of muskmelon. The relationship between available potassium during the experimental season and leaf potassium content at flowering stage is shown in Fig. 3 and it is described as Eq. [3] by curve fitting the related data of Expt. 1.
$\mathrm{K}_{1}=\mathrm{K}_{1, \max } \times\left(1-\exp \left(-\mathrm{rK}_{1} \times \mathrm{K}_{\mathrm{s}} / \mathrm{K}_{1, \text { max }}\right)\right)$,

where $K_{1}\left(\mathrm{mg} \cdot \mathrm{g}^{-1}\right)$ is the leaf potassium content at flowering stage, $\mathrm{K}_{\mathrm{s}}\left(\mathrm{kg} \cdot \mathrm{ha}^{-1}\right)$ is the available potassium during the experimental season, $\mathrm{K}_{1, \max }\left(\mathrm{mg} \cdot \mathrm{g}^{-1}\right)$ is the maximum value of leaf potassium content at flowering stage while available potassium during the experimental season was saturated, and $\mathrm{rK}_{1}\left[\left(\mathrm{mg} \cdot \mathrm{g}^{-1}\right) /\left(\mathrm{kg} \cdot \mathrm{ha}^{-1}\right)\right]$ is the increasing rate of leaf potassium content.

Simulation of leaf gross photosynthetic rate. The negative exponential equation (Goudriaan and Van Laar, 1994) was used to calculate leaf gross photosynthetic rate (Eq. [4]):

$$
\mathrm{P}_{\mathrm{g}}=\mathrm{P}_{\mathrm{g}, \max } \times\left(1-\exp \left(-\varepsilon \times P A R / \mathrm{P}_{\mathrm{g}, \text { max }}\right)\right),
$$

where $\mathrm{P}_{\mathrm{g}}\left(\mathrm{mmol} \mathrm{CO} \mathrm{CO}_{2} / \mathrm{m}^{2} / \mathrm{s}\right)$ is the leaf gross photosynthetic rate, $\varepsilon\left(\mathrm{mmol} \mathrm{CO}_{2} / \mathrm{mmol}\right.$ $P A R)$ is the leaf initial light use efficiency [0.066 according to Yuan et al. (2006)], $P A R\left(\mathrm{mmol} \cdot \mathrm{m}^{2} \cdot \mathrm{s}^{-1}\right)$ is $P A R, \mathrm{P}_{\mathrm{g}, \max }(\mathrm{mmol}$ $\left.\mathrm{CO}_{2} / \mathrm{m}^{2} / \mathrm{s}\right)$ is the $P A R$-saturated leaf gross photosynthetic rate at the flowering stage and determined as function of the leaf potassium content at flowering stage by curve fitting the data of Expt. 1 (Eq. [5], Fig. 4).
$\mathrm{Pg}, \max =\left\{\begin{array}{l}\mathrm{Pg}, \max (0) \quad\left(\mathrm{K}_{1} \geq \mathrm{K}_{\mathrm{c}}\right) \\ \mathrm{Pg}, \max (0) \times(1+\mathrm{rPg}, \max \\ \left.\times\left(\mathrm{K}_{1}-\mathrm{K}_{\mathrm{c}}\right)\right)\left(\mathrm{K}_{1}<\mathrm{K}_{\mathrm{c}}\right),\end{array}\right.$

where $\mathrm{P}_{\mathrm{g}, \max }(0)\left(\mathrm{mmol} \mathrm{CO}_{2} / \mathrm{m}^{2} / \mathrm{s}\right)$ is the $P A R$-saturated leaf gross photosynthetic rate while the leaf potassium content at flowering stage was saturated (i.e., $\mathrm{K}_{1} \geq \mathrm{K}_{\mathrm{c}}$ ), $\mathrm{K}_{1}$ $\left(\mathrm{mg} \cdot \mathrm{g}^{-1}\right)$ is the leaf potassium content at flowering stage, $\mathrm{K}_{\mathrm{c}}\left(\mathrm{mg} \cdot \mathrm{g}^{-1}\right)$ is the critical value of leaf potassium content at flowering stage $\left(55 \mathrm{mg} \cdot \mathrm{g}^{-1}\right.$ and $46 \mathrm{mg} \cdot \mathrm{g}^{-1}$ for 'Nanhaimi' and 'Xizhoumi 25', respectively, according to Expt. 1, and $\mathrm{rP}_{\mathrm{g}, \max }$ is the increasing rate of $\mathrm{P}_{\mathrm{g} \text {, max }}$ along with $\mathrm{K}_{1}$. The values are shown in Table 3.

Simulation of LAI. According to the relationship between the measured leaf area and leaf length, the LAI is calculated as follows (Eqs. [6] and [7]):

$$
\begin{gathered}
\mathrm{LA}=\mathrm{k} \times \mathrm{LL}^{2} \\
\mathrm{LAI}=\sum \mathrm{LA} \times \rho,
\end{gathered}
$$

where LA $\left(\mathrm{m}^{2}\right)$ is the leaf area, LL $(\mathrm{m})$ is the leaf length, $\mathrm{k}$ is the empirical coefficient [0.62 and 0.59 for 'Nanhaimi' and 'Xizhoumi 25', according to Yang et al. (2015)], LAI
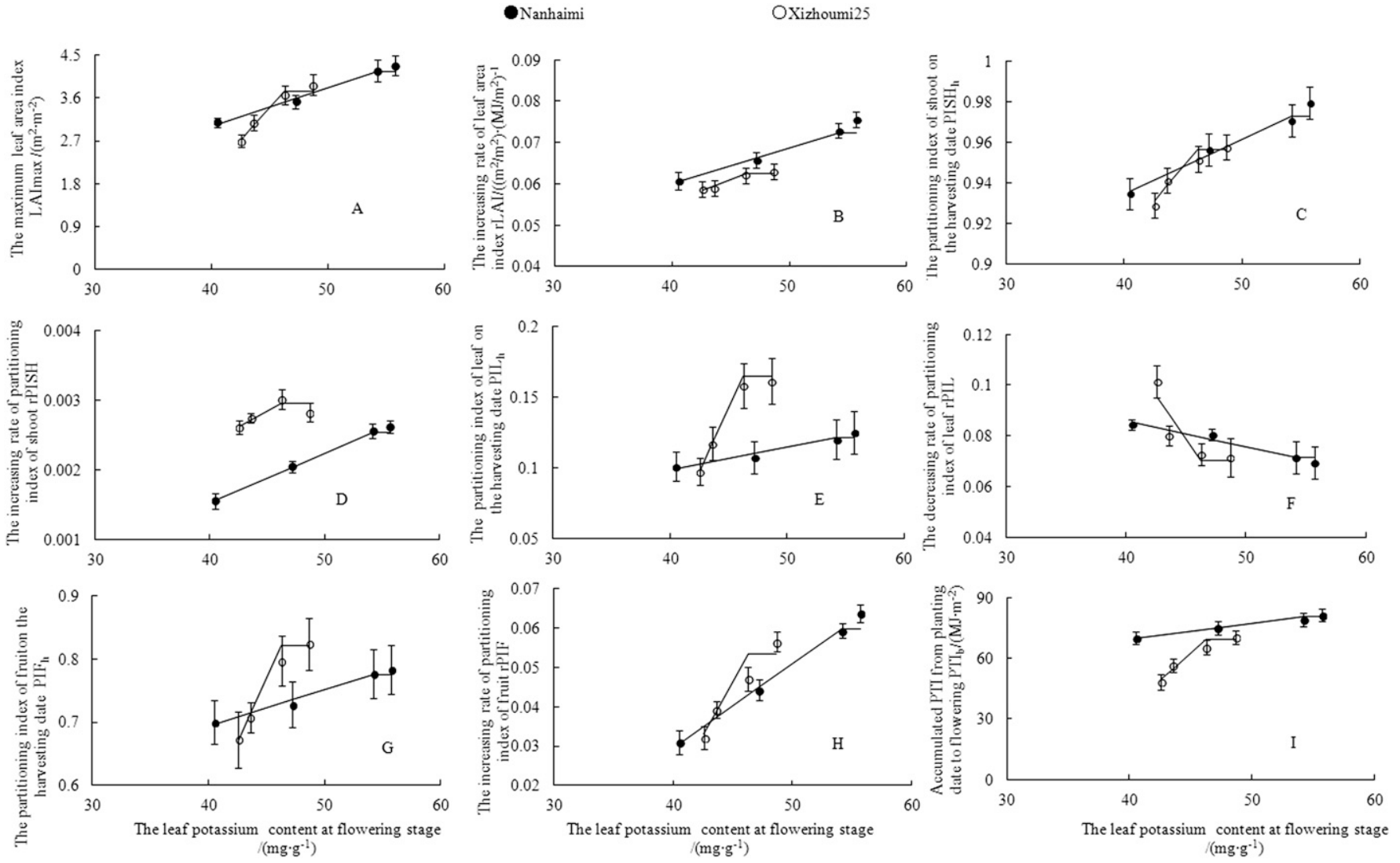

Fig. 6. Relationship between the maximum value of leaf area index $\left(\mathrm{LAI}_{\max }\right)$, the increasing rate of LAI (rLAI), the partitioning index of shoot on the harvest date $\left(\mathrm{PISH}_{\mathrm{h}}\right)$, the increasing rate of partitioning index of shoot ( $\left.\mathrm{rPISH}\right)$, the partitioning index of leaf on the harvest date $\left(\mathrm{PIL}_{\mathrm{h}}\right)$, the increasing rate of partitioning index of leaf (rPIL), the partitioning index of fruit on the harvest date $\left(\mathrm{PIF}_{\mathrm{h}}\right)$, the increasing rate of partitioning index of fruit (rPIF), accumulated PTI from planting date to flowering $\left(\mathrm{PTI}_{\mathrm{b}}\right)$, and the leaf potassium content at flowering stage $\left(\mathrm{K}_{1}\right)$. 
$\left(\mathrm{m}^{2} / \mathrm{m}^{2}\right)$ is the LAI, and $\rho$ (plant $\left./ \mathrm{m}^{2}\right)$ is the planting density, respectively.

The relationship between LAI and the accumulated PTI since planting date under different potassium supply conditions is shown in Fig. 5A and B. LAI was described as Eq. [8] by curve fitting the data in Expt. 1.

$$
\begin{aligned}
\mathrm{LAI}= & \mathrm{LAI}_{0}+\mathrm{LAI}_{\text {max }} \\
& \times\left(1-\exp \left(-\mathrm{rLAI} \times \mathrm{PTI}_{\text {sum }} / \mathrm{LAI}_{\text {max }}\right)\right),
\end{aligned}
$$

where LAI $\left(\mathrm{m}^{2} \cdot \mathrm{m}^{-2}\right)$ is the LAI, $\mathrm{LAI}_{0}\left(\mathrm{~m}^{2} \cdot \mathrm{m}^{-2}\right)$ is the LAI of planting date $(0.09$ and 0.08 for 'Nanhaimi' and 'Xizhoumi 25' according to
Expt. 1), $\mathrm{PTI}_{\text {sum }}\left(\mathrm{MJ} \cdot \mathrm{m}^{-2}\right)$ is the accumulated PTI since planting date, $\mathrm{LAI}_{\max }\left(\mathrm{m}^{2} \cdot \mathrm{m}^{-2}\right)$ is the maximum value of LAI, and rLAI $\left[\left(\mathrm{m}^{2} \cdot \mathrm{m}^{-2}\right) /\left(\mathrm{MJ} \cdot \mathrm{m}^{-2}\right)\right]$ is the increasing rate of LAI, respectively.

Parameter $\mathrm{LAI}_{\max }$ and rLAI were determined as functions of leaf potassium content at flowering stage (Eqs. [9] and [10], Fig. 6A and B).
$443 \mathrm{~kg} \mathrm{~K} / \mathrm{hm}^{2} \quad 0548 \mathrm{~kg} \mathrm{~K} / \mathrm{hm}^{2}$ Nanhaimi
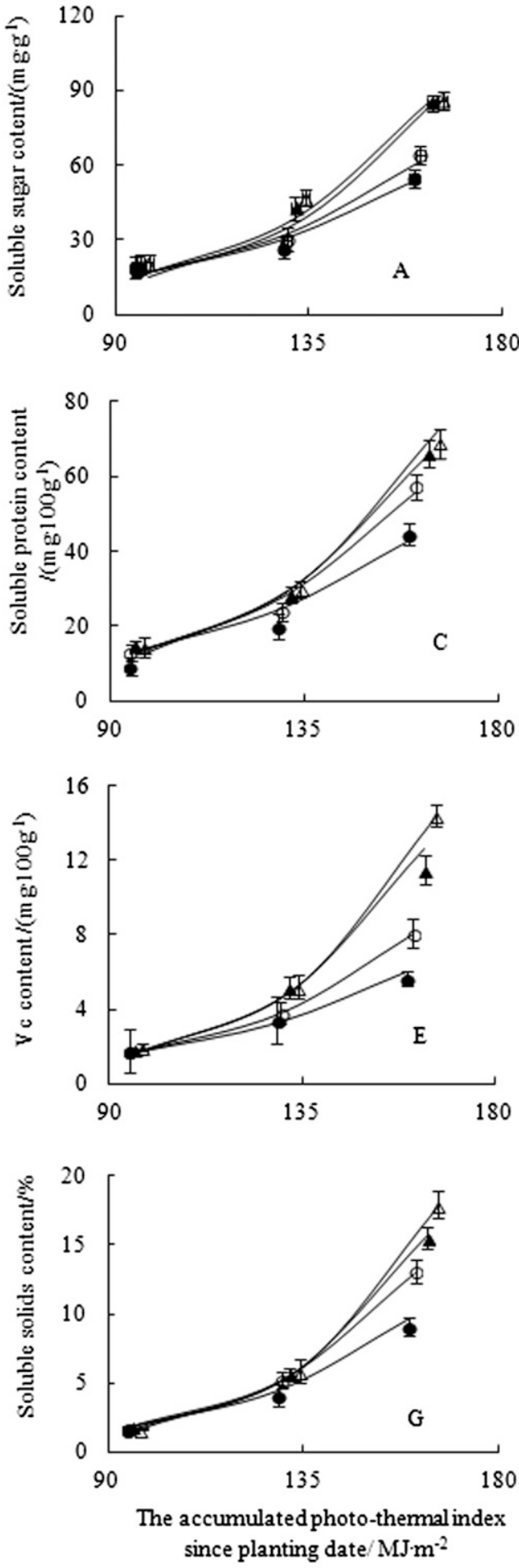

$\Delta 675 \mathrm{~kg} \mathrm{~K} / \mathrm{hm}^{2} \Delta 803 \mathrm{~kg} \mathrm{~K} / \mathrm{hm}^{2}$ Xizhoumi 25
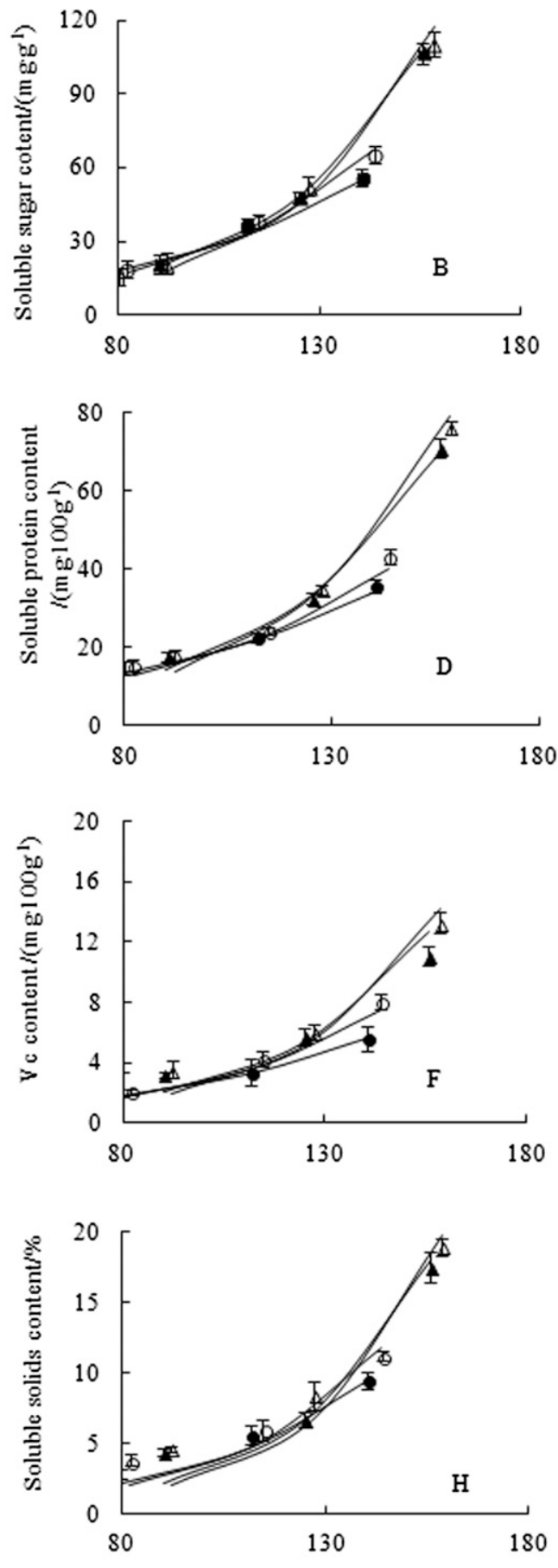

The accumulated photo-thermal index since planting date $/ \mathrm{MJ}^{-2}$

Fig. 7. Relationship between soluble sugar content (SU), soluble protein content (PR), vitamin C content (Vc) and soluble solids content (SO) and the accumulated photothermal index since planting date $\left(\mathrm{PTI}_{\text {sum }}\right)$ under different potassium supply conditions. 


$$
\begin{gathered}
\operatorname{LAImax}=\left\{\begin{array}{lr}
\operatorname{LAImax}(0) & \left(\mathrm{K}_{1} \geq \mathrm{K}_{\mathrm{c}}\right) \\
\operatorname{LAImax}(0) \times(1+\mathrm{rLAImax} \\
\left.\times\left(\mathrm{K}_{1}-\mathrm{K}_{\mathrm{c}}\right)\right)\left(\mathrm{K}_{1}<\mathrm{K}_{\mathrm{c}}\right)
\end{array}\right. \\
\operatorname{rLAI}(0)=\left\{\begin{array}{c}
\operatorname{rLAI}(0) \\
\operatorname{rLAI}(0) \times(1+\operatorname{rrLAI} \\
\left.\times\left(\mathrm{K}_{1}-\mathrm{K}_{\mathrm{c}}\right)\right)\left(\mathrm{K}_{1}<\mathrm{K}_{\mathrm{c}}\right),
\end{array}\right.
\end{gathered}
$$

where $\operatorname{LAI}_{\max }(0)$ and $\operatorname{LAI}(0)$ are the value of $\mathrm{LAI}_{\max }$ and rLAI while the leaf potassium content at flowering stage was saturated (i.e., $\mathrm{K}_{1} \geq \mathrm{K}_{\mathrm{c}}$ ), $\mathrm{rLAI}_{\max }$ and rrLAI are the increasing rate of LAI and rLAI along with $\mathrm{K}_{1}$. The values are shown in Table 3.

Simulation of dry matter partitioning. The relationship between partitioning index of different organs and the accumulated PTI since planting date under different potassium supply conditions is shown in Fig. 5C-J and described as Eqs. [11] to [14] by curve fitting the data in Expt. 1.

$$
\begin{aligned}
\mathrm{PISH}= & \mathrm{PISH}_{\mathrm{p}}+\left(\mathrm{PISH}_{\mathrm{h}}-\mathrm{PISH}_{\mathrm{p}}\right) \\
& \times\left(1-\exp \left(-\mathrm{rPISH} \times \mathrm{PTI}_{\mathrm{sum}} / \mathrm{PISH}_{\mathrm{h}}\right.\right. \\
& \left.\left.-\mathrm{PISH}_{\mathrm{p}}\right)\right)
\end{aligned}
$$

$$
\begin{aligned}
\mathrm{PIL}= & \mathrm{PIL}_{\mathrm{p}}+\left(\mathrm{PIL}_{\mathrm{p}}-\mathrm{PIL}_{\mathrm{h}} / 1\right. \\
& \left.+\exp \left(\mathrm{rPIL} \times\left(\mathrm{PTI}_{\text {sum }}-\mathrm{PTI}_{\mathrm{b}}\right)\right)\right)
\end{aligned}
$$

$$
\begin{aligned}
\mathrm{PIF}= & \mathrm{PIF}_{\mathrm{h}} \times(1-\exp (-\mathrm{rPIF} \\
& \left.\left.\times\left(\mathrm{PTI}_{\text {sum }}-\mathrm{PTI}_{\mathrm{b}}\right)\right)\right) \\
& \mathrm{PIST}=1-\mathrm{PIL}-\mathrm{PIF}
\end{aligned}
$$

where $\mathrm{PISH}_{\mathrm{p}}$ and $\mathrm{PIL}_{\mathrm{p}}$ are the partitioning index of shoot and leaf on the planting date $(0.83$ and 0.70 for 'Nanhaimi' and 'Xizhoumi 25', according to Expt. 1); $\mathrm{PISH}_{\mathrm{h}}$, $\mathrm{PIL}_{\mathrm{h}}$, and $\mathrm{PIF}_{\mathrm{h}}$ are the partitioning index of shoot, leaf, and fruit on the harvest date; rPISH, rPIL, and rPIF are the increasing rate of partitioning index of shoot, leaf, and fruit; $\mathrm{PTI}_{\text {sum }}\left(\mathrm{MJ} / \mathrm{m}^{2}\right)$ is the accumulated PTI since planting date; and $\mathrm{PTI}_{\mathrm{b}}\left(\mathrm{MJ} / \mathrm{m}^{2}\right)$ is the accumulated PTI from planting date to flowering, respectively.

The impacts of leaf potassium content at flowering stage on parameters $\left(\mathrm{PISH}_{\mathrm{h}}\right.$, rPISH, PIL ${ }_{h}, r$ PIL, PIF, rPIF, and PTI PI $_{h}$ are shown in Fig. 6C-I and described as Eq. [15] by curve fitting the data in Expt. 1.

$$
X=\left\{\begin{array}{l}
X(0) \quad\left(K_{1} \geq K_{c}\right) \\
X(0) \times(1+r X \\
\left.\quad \times\left(K_{1}-K_{c}\right)\right)\left(K_{1}<K_{c}\right),
\end{array}\right.
$$

where $\mathrm{X}$ is the $\mathrm{PISH}_{\mathrm{h}}$, rPISH, PIL $\mathrm{h}$, rPIL, $\mathrm{PIF}_{\mathrm{h}}, \mathrm{rPIF}$, and $\mathrm{PTI}_{\mathrm{b}} ; \mathrm{X}(0)$ is the values of $\mathrm{PISH}_{\mathrm{h}}, \mathrm{rPISH}, \mathrm{PIL}_{\mathrm{h}}, \mathrm{rPIL}, \mathrm{PIF}_{\mathrm{h}}$, rPIF, and
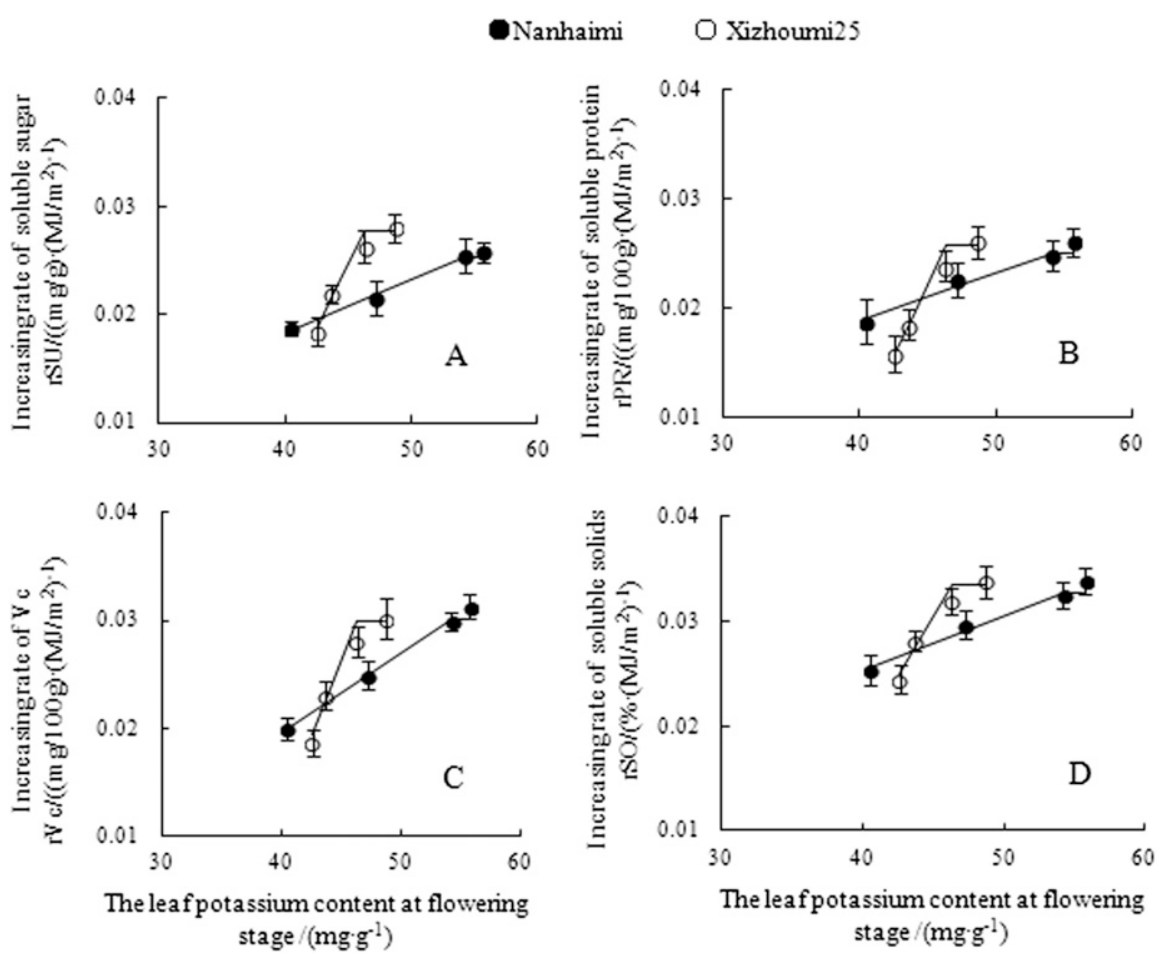

Fig. 8. Relationship between the increasing rate of soluble sugar (rSU), the increasing rate of soluble protein $(\mathrm{rPR})$, the increasing rate of vitamin $\mathrm{C}(\mathrm{rVc})$, the increasing rate of soluble solids $(\mathrm{rSO})$, and the leaf potassium content at flowering stage $\left(\mathrm{K}_{1}\right)$.
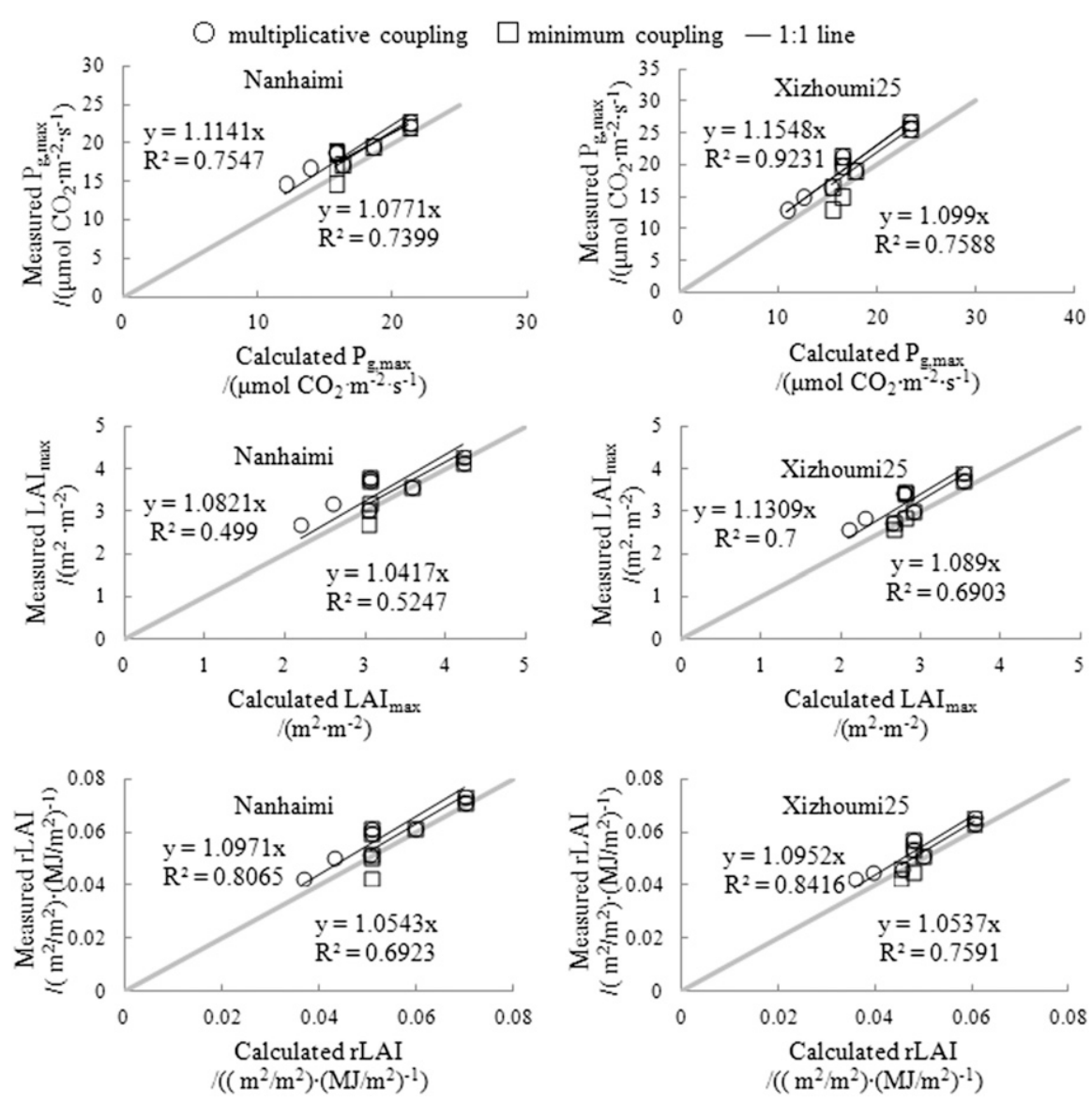

Fig. 9. The 1:1 line of calculated and measured values of maximum leaf gross photosynthetic rate $\left(\mathrm{P}_{\mathrm{g}, \max }\right)$, maximum value of leaf area index $\left(\mathrm{LAI}_{\max }\right)$, the increasing rate of $\mathrm{LAI}(\mathrm{rLAI})$ of two coupling ways. 
$\mathrm{PTI}_{\mathrm{b}}$ while the leaf potassium content at flowering stage was saturated (i.e., $\mathrm{K}_{1} \geq$ $\mathrm{K}_{\mathrm{c}}$ ); $\mathrm{rX}$ is the increasing rate of the parameter along with the leaf potassium content at flowering stage. The values are shown in Table 3.

Simulation of fruit quality traits. The relationship between fruit quality traits and the accumulated PTI since planting date under different potassium supply conditions is shown in Fig. 7 and described as Eqs. [16] to [19] by curve fitting the data in Expt. 1.

$$
\mathrm{SU}=\mathrm{SU}_{0} \times \exp \left(\mathrm{rSU} \times\left(\mathrm{PTI}_{\text {sum }}-\mathrm{PTI}_{\mathrm{b}}\right)\right)
$$

$$
\mathrm{PR}=\mathrm{PR}_{0} \times \exp \left(\mathrm{rPR} \times\left(\mathrm{PTI}_{\text {sum }}-\mathrm{PTI}_{\mathrm{h}}\right)\right)
$$

$$
\mathrm{V}_{\mathrm{c}}=\mathrm{V}_{\mathrm{C}_{0}} \times \exp \left(\mathrm{rV}_{\mathrm{c}} \times\left(\mathrm{PTI}_{\text {sium }}-\mathrm{PTI}_{\mathrm{h}}\right)\right)
$$

$$
\mathrm{SO}=\mathrm{SO}_{0} \times \exp \left(\mathrm{rSO} \times\left(\mathrm{PTI}_{\text {sum }}-\mathrm{PTI}_{\mathrm{b}}\right)\right),
$$

where $\mathrm{SU}_{0}, \mathrm{PR}_{0}, \mathrm{Vc}_{0}$, and $\mathrm{SO}_{0}$ are the initial content of SU, PR, Vc, and SO $\left(10 \mathrm{mg} \cdot \mathrm{g}^{-1}\right.$, $8 \mathrm{mg} / 100 \mathrm{~g}, 1 \mathrm{mg} / 100 \mathrm{~g}$, and $1 \%$, the same value for 'Nanhaimi' and 'Xizhoumi 25', according to Expt. 1), $\mathrm{PTI}_{\text {sum }}\left(\mathrm{MJ} \cdot \mathrm{m}^{-2}\right)$ was the accumulated PTI since planting date, and $\mathrm{PTI}_{\mathrm{b}}\left(\mathrm{MJ} \cdot \mathrm{m}^{-2}\right)$ was the accumulated PTI from planting date to flowering.

The impacts of leaf potassium content at flowering stage on parameters (rSU, rPR, $\mathrm{rVc}$, and rSO) are shown in Fig. 8 and described as Eqs. [20] to [23] by curve fitting the data in Expt. 1.

$$
\begin{aligned}
& \mathrm{rSU}=\left\{\begin{array}{l}
\mathrm{rSU}(0) \quad\left(\mathrm{K}_{1} \geq \mathrm{K}_{\mathrm{c}}\right) \\
\mathrm{rSU}(0) \times(1+\mathrm{rrSU} \\
\left.\times\left(\mathrm{K}_{1}-\mathrm{K}_{\mathrm{c}}\right)\right)\left(\mathrm{K}_{1}<\mathrm{K}_{\mathrm{c}}\right)
\end{array}\right. \\
& \mathrm{rPR}=\left\{\begin{array}{l}
\mathrm{rPR}(0) \quad\left(\mathrm{K}_{1} \geq \mathrm{K}_{\mathrm{c}}\right) \\
\mathrm{rPR}(0) \times(1+\mathrm{rPR} \\
\left.\times\left(\mathrm{K}_{1}-\mathrm{K}_{\mathrm{c}}\right)\right)\left(\mathrm{K}_{1}<\mathrm{K}_{\mathrm{c}}\right)
\end{array}\right. \\
& \mathrm{rVc}=\left\{\begin{array}{l}
\mathrm{rVc}(0) \quad\left(\mathrm{K}_{1} \geq \mathrm{K}_{\mathrm{c}}\right) \\
\mathrm{rVc}(0) \times(1+\mathrm{rVc} \\
\left.\times\left(\mathrm{K}_{1}-\mathrm{K}_{\mathrm{c}}\right)\right)\left(\mathrm{K}_{1}<\mathrm{K}_{\mathrm{c}}\right)
\end{array}\right. \\
& \mathrm{rSO}=\left\{\begin{array}{l}
\mathrm{rSO}(0) \quad\left(\mathrm{K}_{1} \geq \mathrm{K}_{\mathrm{c}}\right) \\
\mathrm{rSO}(0) \times(1+\mathrm{rrSO} \\
\left.\times\left(\mathrm{K}_{1}-\mathrm{K}_{\mathrm{c}}\right)\right)\left(\mathrm{K}_{1}<\mathrm{K}_{\mathrm{c}}\right),
\end{array}\right.
\end{aligned}
$$

where $\mathrm{rSU}(0), \mathrm{rPR}(0), \mathrm{rVc}(0)$, and $\mathrm{rSO}(0)$ are the values of $\mathrm{rSU}, \mathrm{rPR}, \mathrm{rVc}$, and $\mathrm{rSO}$ while the leaf potassium content at flowering stage was saturated (i.e., $\mathrm{K}_{1} \geq \mathrm{K}_{\mathrm{c}}$ ); rrSU, rrPR, $\mathrm{rrVc}$, and $\mathrm{rSO}$ are the increasing rate of these parameters along with the leaf potassium content at flowering stage. The values are shown in Table 3.
Predicting dry weight of organ and fruit quality. According to Eqs. [1] to [23], a model of plastic greenhouse muskmelon was developed by integrating the simulation of LAI, seasonal changes of dry matter partitioning, and fruit quality traits into the existing SUCROS, which could be used to predict the impacts of potassium on dry matter production and fruit quality. DWSH, DWL, DWST, and DWF were estimated in Eqs. [24] to [27].
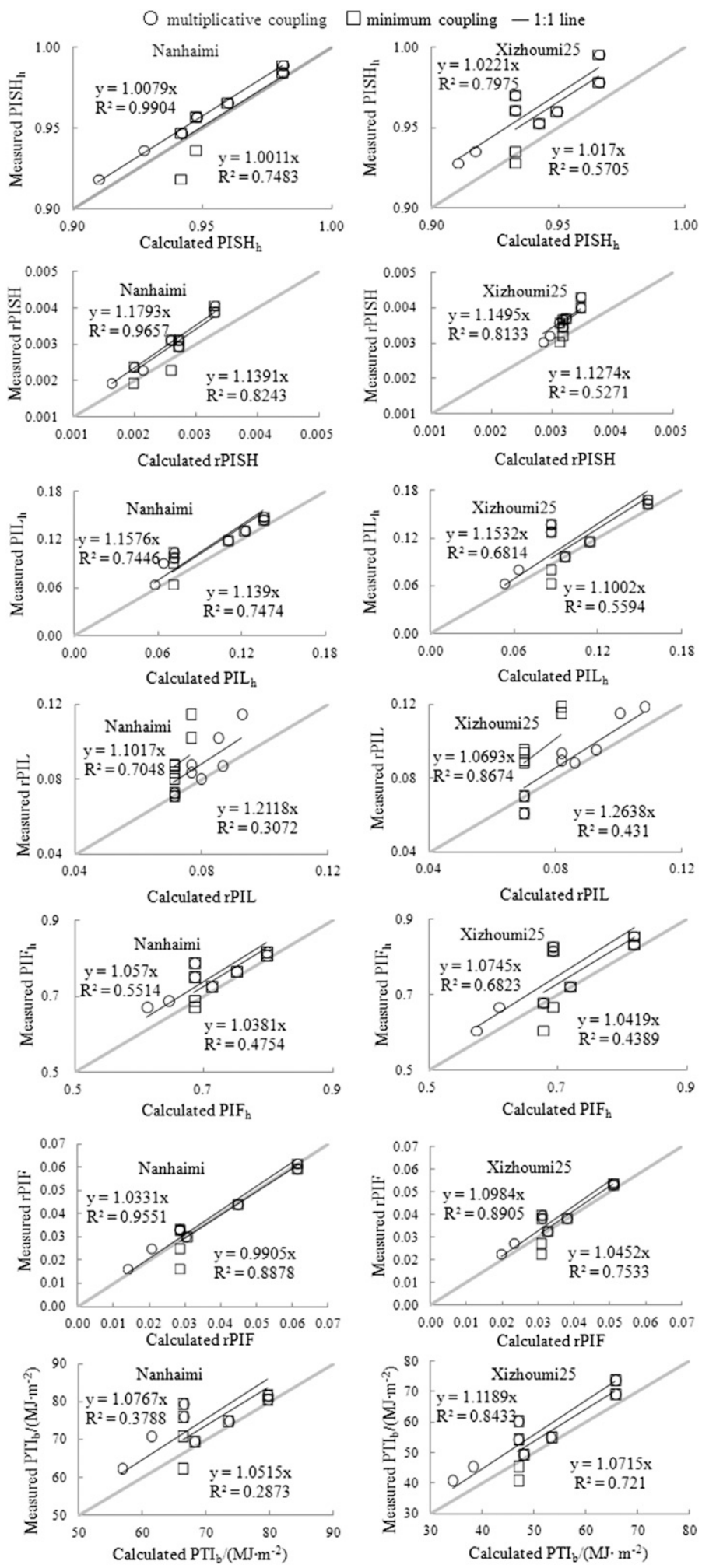

Fig. 10. The 1:1 line of calculated and measured value of the partitioning index of shoot on the harvest date $\left(\mathrm{PISH}_{\mathrm{h}}\right)$, the increasing rate of partitioning index of shoot (rPISH), the partitioning index of leaf on the harvest date $\left(\mathrm{PIL}_{\mathrm{h}}\right)$, the increasing rate of partitioning index of leaf (rPIL), the partitioning index of fruit on the harvest date $\left(\mathrm{PIF}_{\mathrm{h}}\right)$, the increasing rate of partitioning index of fruit ( $\left.\mathrm{PPIF}\right)$, accumulated PTI from planting date to flowering $\left(\mathrm{PTI}_{\mathrm{b}}\right)$ of two coupling ways. 
DWSH $=$ BIOMASS $\times$ PISH

$$
\mathrm{DWL}=\mathrm{DWS} \times \mathrm{PIL}
$$

$$
\mathrm{DWST}=\mathrm{DWS} \times \mathrm{PIST}
$$

$$
\mathrm{DWF}=\mathrm{DWS}-\mathrm{DWL}-\mathrm{DWST}
$$

Predicting the fruit yield. The yield of fruiting vegetables was mainly dependent on fresh weight of individual fruit at harvest. The relationship between dry weight and FWF was described as Eq. [28] by curve fitting the data of Expt. 1.

$$
\mathrm{FWF}=\mathrm{DWF} \times \mathrm{g},
$$

where DWF (g/plant) is the dry weight of fruit, and $\mathrm{g}$ is the empirical coefficient ( 11.45 and 12.10 for 'Nanhaimi' and 'Xizhoumi 25', according to Expt. 1).

Methods for model validation. The coefficient of determination of linear regression $\left(r^{2}\right)$ and the relative rRMSE between the predicted and measured values were used for model validation. The $r^{2}$ and rRMSE were calculated as Eqs. [29] and [30]:

$$
\begin{array}{r}
r^{2}=\frac{\left(\sum(x-\bar{x})(y-\bar{y})\right)^{2}}{\sum(x-\bar{x})^{2} \sum(y-\bar{y})^{2}} \\
\mathrm{rRMSE}=\frac{1}{\bar{x}} \sqrt{\frac{\sum_{i=1}^{n}(x-y)^{2}}{n}},
\end{array}
$$

where $x$ is the measured value, $y$ is the predicted value, $\bar{x}$ is the average of measured value, $\bar{y}$ is the average of predicted value, and $n$ is the number of samples.

The ways of nitrogen and potassium coupling. Two ways for nitrogen and potassium coupling were multiplicative coupling and minimum coupling, and described as follows (Eqs. [31] and [32]):

$$
\begin{array}{r}
X=K \times X(0) \times f_{N} \times f_{K} \\
X=K \times X(0) \times \operatorname{Min}\left(f_{N} \times f_{k}\right),
\end{array}
$$

where $\mathrm{K}$ is the coupling coefficient that was shown in Figs. 9 to 11 (constants of the curve equations), $\mathrm{X}$ is the calculated value of the parameter, $\mathrm{X}(0)$ is the value of the parameter while the leaf nitrogen and potassium content at flowering stage was saturated, $\mathrm{f}_{\mathrm{N}}$ is the nitrogen limit factor, and $f_{K}$ is the potassium limit factor, respectively.

The 1:1 line of calculated value and measured value for parameters are shown in Figs. 9-11; the curve equation and its coefficient of determination $\left(R^{2}\right)$ of multiplicative coupling and minimum coupling are shown on the left and right side of the line, respectively. The calculated values were described by Eqs. [31] to [32], and the measured values were the data obtained from Expt. 3 . As shown in Figs. 9-11, calculated value of multiplicative coupling was closer to the measured value than minimum coupling (except some quality parameters). Due to its greater $R^{2}$, it is a better way of nitrogen and
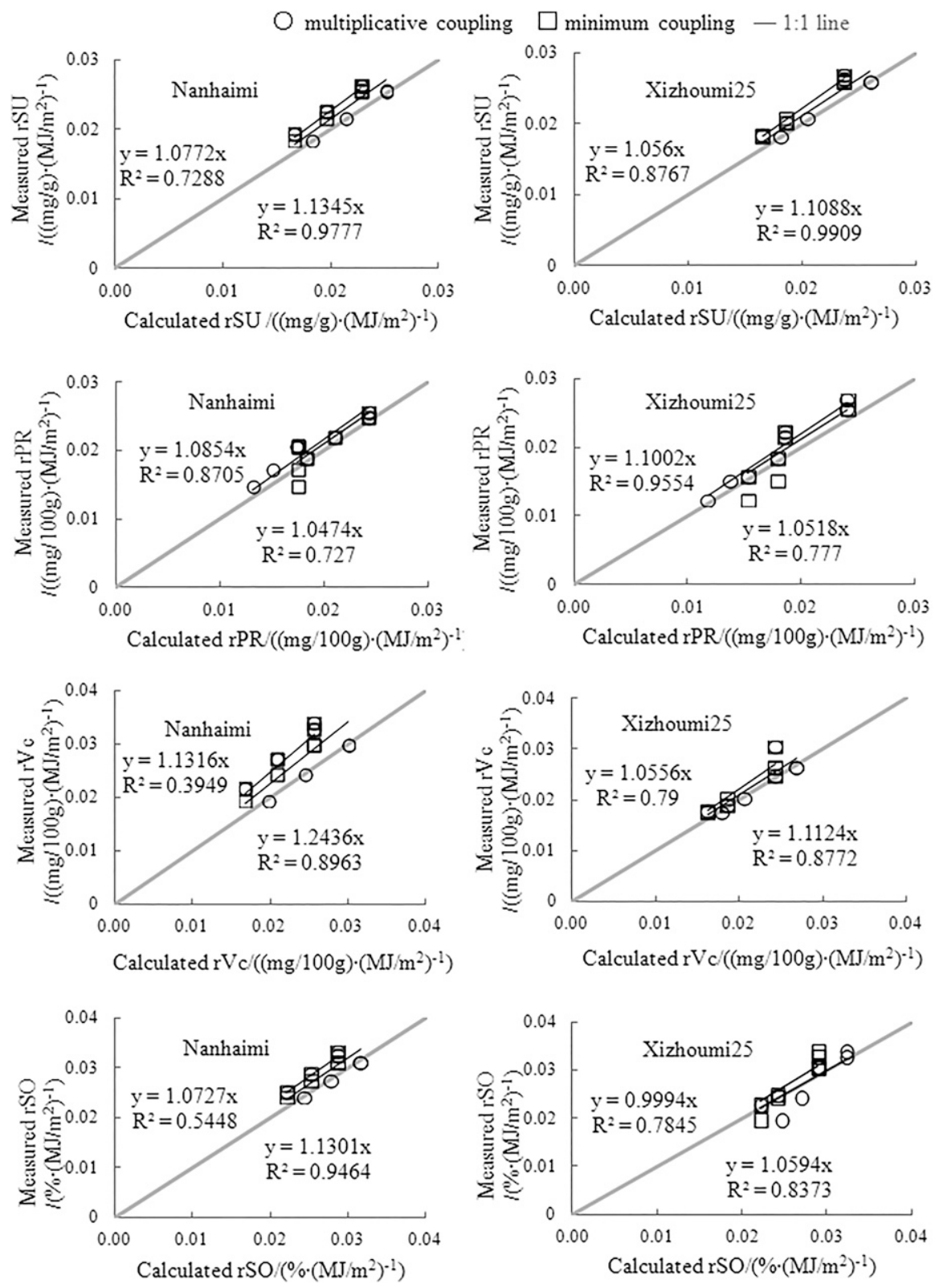

Fig. 11. The 1:1 line of calculated and measured value of the increasing rate of soluble sugar (rSU), the increasing rate of soluble protein $(\mathrm{rPR})$, the increasing rate of vitamin $\mathrm{C}(\mathrm{rVc})$, and the increasing rate of soluble solids (rSO) of two coupling ways.

potassium coupling for parameters, and could be used in model development.

To quantify the impacts of leaf nitrogen and potassium contents at flowering stage on the growth and quality of muskmelon, Eq. [31] can be further described as Eq. [33]:

$$
\begin{aligned}
\mathrm{X}= & \mathrm{K} \times \mathrm{X}(0) \times(1+\mathrm{rXN} \\
& \left.\times\left(\mathrm{N}_{1}-\mathrm{N}_{\mathrm{c}}\right)\right)\left(1+\mathrm{rXK} \times\left(\mathrm{K}_{1}-\mathrm{K}_{\mathrm{c}}\right)\right),
\end{aligned}
$$

where $\mathrm{X}(0)$ is the value of $\mathrm{P}_{\mathrm{g}, \max }$, LAImax, rLAI, PISH $_{h}$, rPISH, PIL $_{h}$, rPIL, PIF, rPIF, $\mathrm{PTIb}, \mathrm{rSU}, \mathrm{rPR}, \mathrm{rVc}$, and $\mathrm{rSO}$ while the leaf nitrogen and potassium content at flowering stage were saturated, and the value of these parameters of 'Nanhaimi' were 21.2, 4.2, $0.07,0.981,0.003,0.135,0.071,0.797$, $0.061,79.6,0.023,0.024,0.026$, and 0.029 , respectively, and were $23.3,3.5,0.061,0.966$, $0.004,0.155,0.07,0.818,0.051,65.6,0.024$, $0.024,0.024$, and 0.029 , respectively, for 'Xizhoumi 25'; rXN and rXK are the increasing rates of these parameters along with the leaf nitrogen and potassium contents at flowering stage [Yang et al. (2015) and Table 3].

\section{Results}

Validate model of potassium. As shown in Figs. 6 and 8, the relationship among leaf potassium content at flowering stage $\left(\mathrm{K}_{1}\right)$, parameters of growth $\left(\mathrm{LAI}_{\max }, \mathrm{rLAI}, \mathrm{PISH}_{\mathrm{h}}\right.$, rPISH, PIL ${ }_{h}$, rPIL, PIF $_{h}$, and rPIF) and quality (rSU, rPR, rVc, and rSO) were increasingly linear with the leaf potassium content at flowering stage. But, these 
parameters did not increase when the leaf potassium content at the flowering stage increased to 55.0 and $46.0 \mathrm{mg} \cdot \mathrm{g}^{-1}$ for 'Nanhaimi' and 'Xizhoumi 25'. Therefore, 55.0 and $46.0 \mathrm{mg} \cdot \mathrm{g}^{-1}$ were determined as the critical leaf potassium content and could be used as indicator of optimal potassium management for muskmelon production. Corresponding to the critical value of leaf potassium content at flowering stage, the available potassium in the substrate of Expt. 1 for the two cultivars were, respectively, $714 \mathrm{~kg} \cdot \mathrm{ha}^{-1}$ for 'Nanhaimi' and 491 $\mathrm{kg} \cdot \mathrm{ha}^{-1}$ for 'Xizhoumi 25'.

Independent experimental data (Expt. 2) were used to validate the model, and the results are shown in Fig. 12. The $r^{2}$ between the predicted and measured values of LAI, DWSH, DWST, DWL, DWF, FWF, SU, PR, $\mathrm{Vc}$, and SO were 0.93, 0.98, 0.83, 0.96, 0.98, $0.99,0.94,0.94,0.89,0.85$, and 0.90 , respectively. The rRMSE between the predicted and measured value were $10.8 \%$, $19.6 \%, \quad 30.3 \%, \quad 21.1 \%, \quad 11.9 \%, \quad 17.2 \%$, $13.9 \%, 27.8 \%, 20.6 \%$, and $10.1 \%$, respectively. Therefore, our research gave satisfactory predictions of growth dynamics and quality for muskmelon under different levels of potassium treatment.

Validate model of nitrogen and potassium coupling. Data of Expt. 4 were used to validate the nitrogen and potassium coupling model, and the results are shown in Fig. 13. The $r^{2}$ between the predicted and measured values of LAI, DWSH, DWST, DWL, DWF, FWF, SU, PR, Vc, and SO were 0.78, 0.91, $0.93,0.94,0.83,0.89,0.92,0.95,0.91$, and 0.93 , respectively. The rRMSE between the predicted and measured value were $9.2 \%$, $12.4 \%, 11.8 \%, 43.2 \%, 6.6 \%, 7.2 \%, 6.85 \%$, $4.98 \%, 6.61 \%$, and $4.35 \%$, respectively. The predicted values of growth dynamics, yield, and quality of muskmelon under different ratios of nitrogen and potassium treatment were closed to the measured values. Therefore, the multiplicative coupling was more proper in model development.

\section{Discussion}

Potassium is generally involved in the maintenance of osmotic potential, cytoplasmic $\mathrm{pH}$ homeostasis, charge balance, enzyme activation, photosynthates translocation, stomatal regulation, and water uptake (Oosterhuis et al., 2014). Previous studies suggested that potassium could improve tomato yield and quality (Hartz et al., 1999). It could promote muskmelon growth, such as dry and fresh weight of shoot, the chlorophyll content, and photosynthetic rate (Wang et al., 2017). Photosynthetic metabolism requires appropriate concentrations of potassium for proper functioning (Marschner and Marschner, 2012). If leaf potassium concentration was less than $0.5 \%$ to $0.6 \%$, it would limit leaf $\mathrm{CO}_{2}$ exchange rate and reduce leaf carbon fixation (Basile et al., 2003). In our study, the LAI, PISH, PIF, SU, $\mathrm{PR}, \mathrm{Vc}$, and SO were increasing linearly along with the available potassium during the experimental season in a certain range, but the
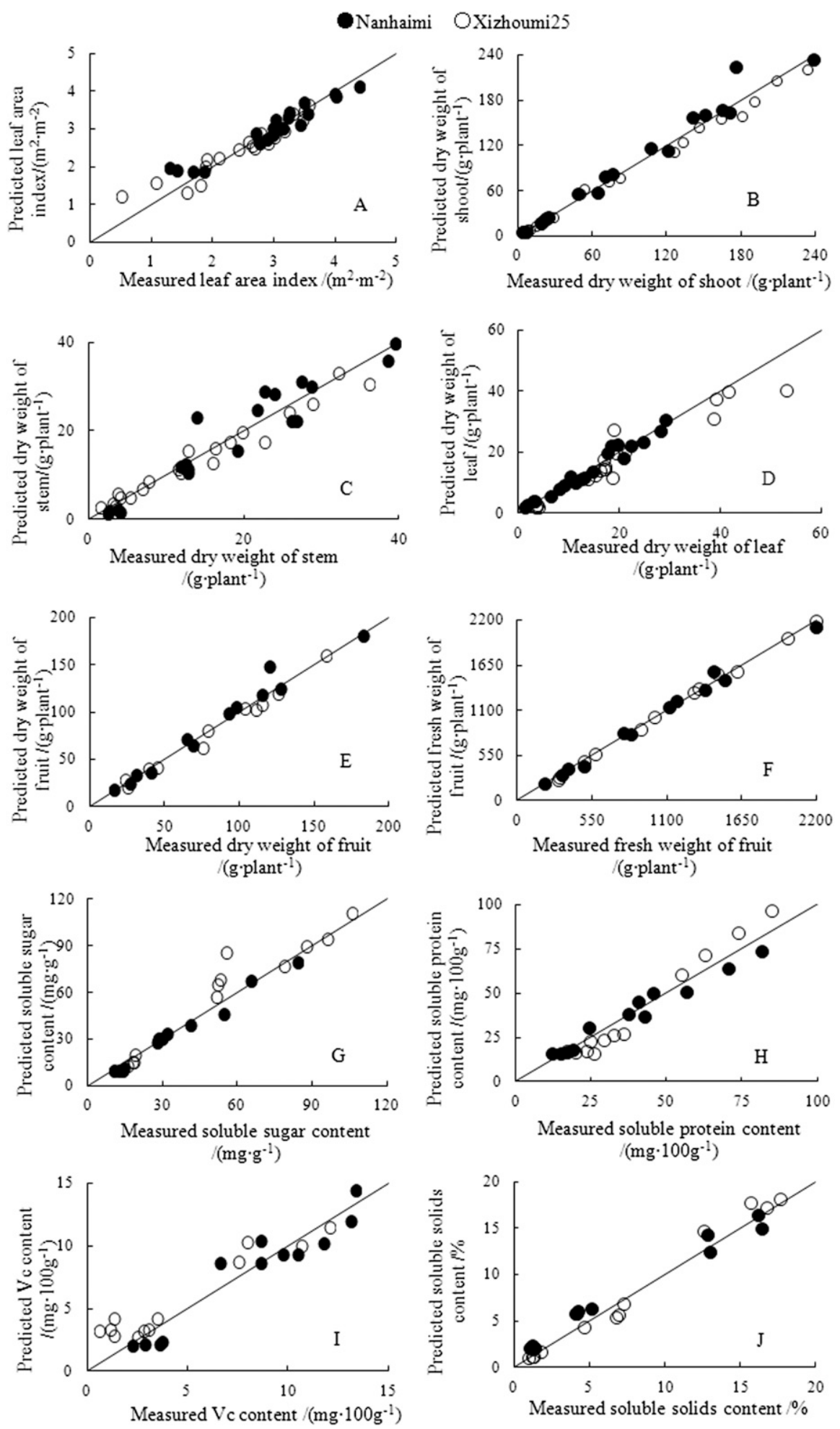

Fig. 12. Comparison between the predicted and measured leaf area index (LAI), dry weight of shoot (DWSH), dry weight of leaf (DWL), dry weight of stem (DWST), dry weight of fruit (DWF), fresh weight of fruit (FWF), soluble sugar content $(\mathrm{SU})$, soluble protein content $(\mathrm{PR})$, vitamin $\mathrm{C}(\mathrm{Vc})$, and soluble solids content (SO) in potassium fertilization experiment.

increase of the value of these parameters was not significant when the available potassium increased to $675 \mathrm{~kg} \cdot \mathrm{ha}^{-1}$; and the $\mathrm{P}_{\mathrm{g}, \max }$, LAImax, rLAI, PISH $_{\mathrm{h}}$, rPISH, PIL $_{\mathrm{h}}, \mathrm{PIF}_{\mathrm{h}}$, rPIF, $\mathrm{PTIb}, \mathrm{rSU}, \mathrm{rPR}, \mathrm{rVc}$, and rSO were also increasing linearly along with the leaf potassium content at the flowering stage before the leaf potassium content increased to 55.0 and
$46.0 \mathrm{mg} \cdot \mathrm{g}^{-1}$ for 'Nanhaimi' and 'Xizhoumi 25'. Therefore, the potassium had a positive effect on the growth and quality of muskmelon, which was basically consistent with former studies (Lin et al., 2004).

With the increase of potassium content in the leaf, the parameters of the two melon varieties had the same change. However, The 
Nanhaimi OXizhoumi25
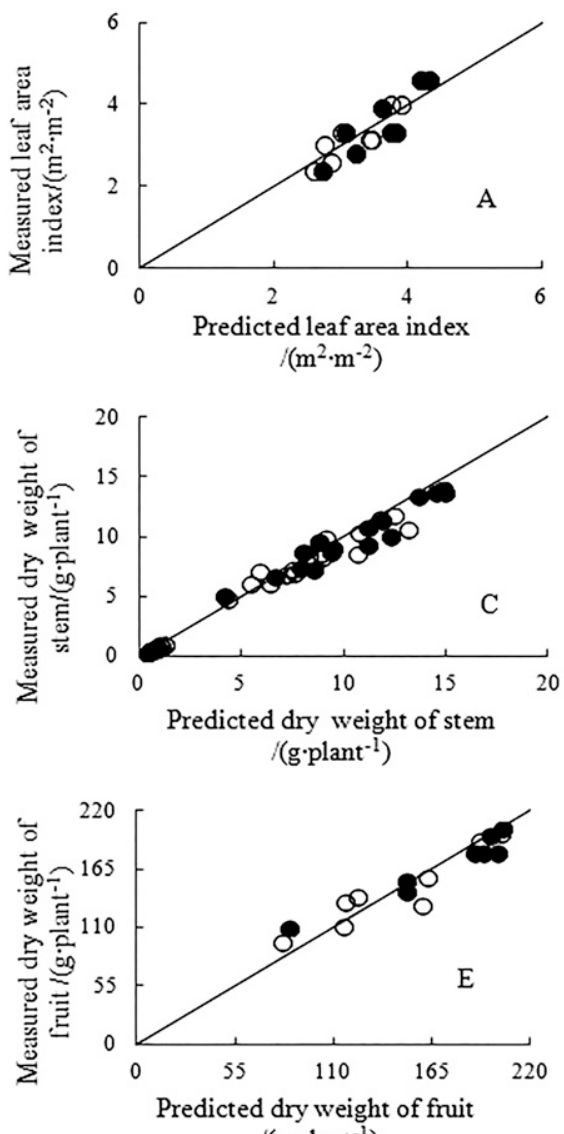

(g.plant $\left.{ }^{-1}\right)$

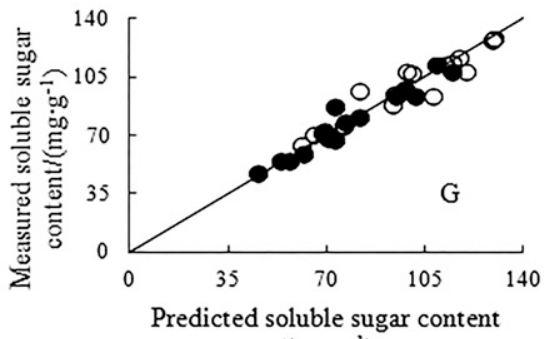

$/\left(\mathrm{mg} \cdot \mathrm{g}^{-1}\right)$

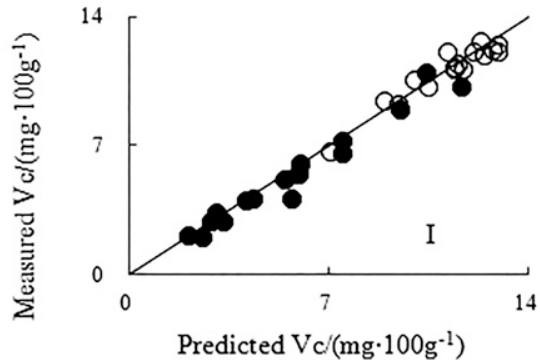

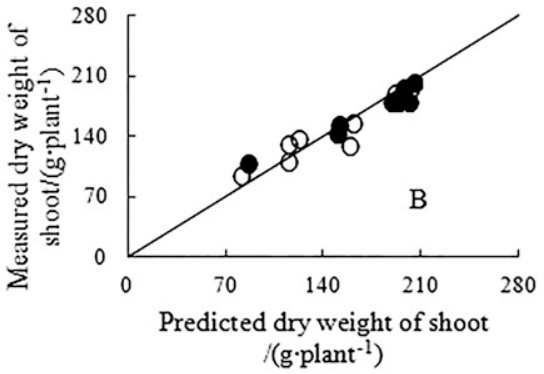
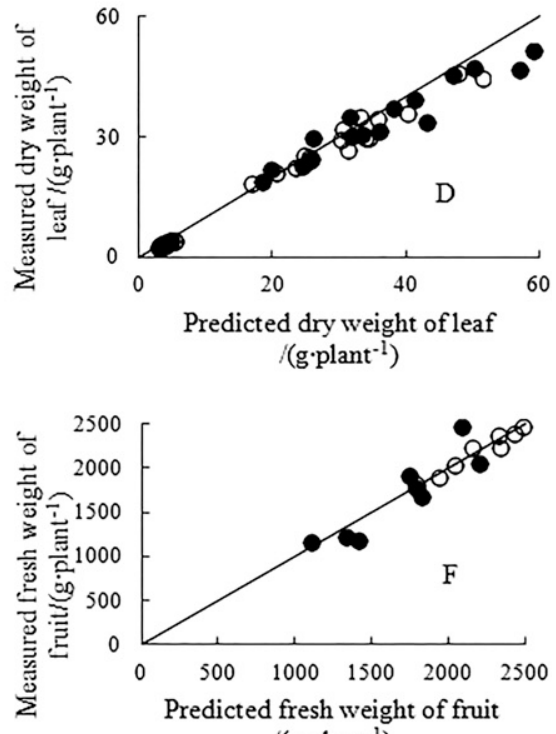

$/\left(\mathrm{g} \cdot\right.$ plant $\left.^{-1}\right)$
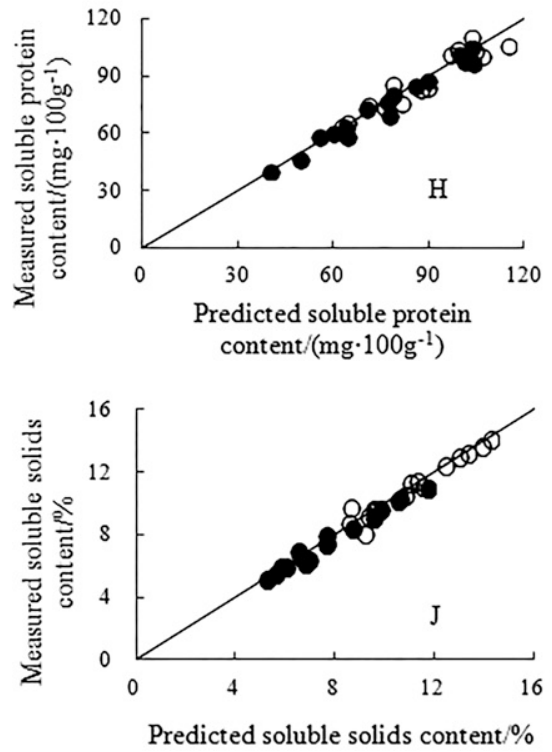

Fig. 13. Comparison between the predicted and measured leaf area index (LAI), dry weight of shoo (DWSH), dry weight of leaf (DWL), dry weight of stem (DWST), dry weight of fruit (DWF), fresh weight of fruit (FWF), soluble sugar content (SU), soluble protein content (PR), vitamin C (Vc), and soluble solids content (SO) in nitrogen and potassium coupling experiment.

change of leaf potassium content had a greater impact on the parameter values of 'Xizhoumi 25', that is, the parameter values of 'Xizhoumi 25' increased or decreased more than 'Nanhaimi' with the same increase of potassium content in leaf. The requirement of available potassium for 'Xizhoumi 25' the requirement of available nitrogen for 'Nanhaimi' was less than 'Xizhoumi 25'. This can be attributed to the fact that different varieties had different characteristics of fertilizer demand. It is necessary to apply fertilizer according to their fertilizer demand characteristics. Therefore, estimating the supply of potassium in the substrate based on leaf potassium content at flowering stage was feasible for different planting dates, varieties, and substrate types, and helpful to ensure the yield and quality of muskmelon and improve the use efficiency of potassium fertilizer. It overcomes the limitation that the model can only be used when planting substrate and planting date are the same. It also extends the applicability of the model, so as to realize reasonable use of potassium in muskmelon production.

According to the coupling way of water and nitrogen of previous studies (Shao, 2010), a single factor model of nitrogen and potassium of muskmelon had be developed first in our study, and the nitrogen and potassium coupling model was developed finally. Two ways of nitrogen and potassium coupling (multiplicative coupling and minimum coupling) were compared in this study, and the result showed that calculated value of growth parameters of multiplicative coupling is closer to the measured value than minimum coupling, but not for the quality parameters. The main reason might be because the effects of nitrogen and potassium on quality parameters is opposite, the effect of nitrogen on most quality parameters is negative [parameters decreased with the increase of leaf nitrogen content (Yang et al., 2015)], but the effect of potassium is positive on these quality parameters (parameters increased along with the leaf potassium content), and that would limit the curve-fitting effect of multiplicative coupling on quality parameters. In this study, just one coupling way was applied in the model development. Further studies are needed to model calibration and test when the models are applied to a wide range of field conditions and muskmelon cultivars.

\section{Conclusion}

In this study, models that accumulated PTI as a growth indicator and leaf potassium content at flowering stage as potassium indicator were developed to quantify the impacts of potassium on growth dynamics, yield, and fruit quality under different levels of potassium treatment. With the planting date, available potassium during the experimental season, the light intensity, the air, and the substrate temperature as inputs, the model can give good predictions of LAI, DWSH, DWL, DWST, DWF, FWF, SU, PR, $\mathrm{Vc}$, and SO of muskmelon. To obtain the same yield and quality on different planting dates, we can keep the same leaf potassium content at the flowering stage by changing the available potassium during the experimental season. 
Based on quantifying the impacts of nitrogen and potassium on the growth dynamics, yield and fruit quality of melon, the way nitrogen and potassium coupling were confirmed, that nitrogen limits factors, potassium limits factors, and coefficients of nitrogen and potassium coupling were multiplied, the coupling way of nitrogen and potassium can be applied to the development of the coupling model.

\section{Literature Cited}

Ardjasa, W.S., T. Abe, A. Ho, K.I. Kakuda, and M. Kimura. 2002. Fate of basal $\mathrm{N}$ and growth of crops cultivated under cassava-based intercropping system with reference to $\mathrm{K}$ application rate. Soil Sci. Plant Nutr. 48:365-370.

Awais, M., W. Aftab, B.M. Usman, H.U.R. Muhammad, R.M.A. Sammar, A. Ashfaq, S.M. Farrukh, H.H. Mohkum, M. Muhammad, S. Umer, A.M. Naveed, F. Shah, and N. Wajid. 2017. Nitrogen and plant population change radiation capture and utilization capacity of sunflower in semi-arid environment. Environ. Sci. Pollut. Res. Intl. 24:17511-17525.

Balliu, A. and V.I. Bro. 2002. Influence of different levels of potassium fertilizers on growth, yield, and ascorbic acid content of tomato fruit grown in non-heated greenhouse. Acta Hort. 579:385-388.

Basile, B., E.J. Reidel, S.A. Weinbaum, and T.M. DeJong. 2003. Leaf potassium concentration, $\mathrm{CO}_{2}$ exchange and light interception in almond trees (Prunus dulcis (Mill) D.A.Webb). Scientia Hort. 98:185-194.

Belay, A., A.S. Claassens, and F. Wehner. 2002. Effect of direct nitrogen and potassium and residual phosphorus fertilizers on soil chemical properties, microbial components and maize yield under long-term crop rotation. Biol. Fertil. Soils 35:420-427.

Burnell, O.W., B.D. Russell, A.D. Irving, and S.D. Connell. 2014. Seagrass response to $\mathrm{CO}_{2}$ contingent on epiphytic algae: Indirect effects can overwhelm direct effects. Oecologia 176:871-882.

Chen, Q., X.S. Zhang, H.Y. Zhang, P. Christie, X.L. Li, D. Horlacher, and H.P. Liebig. 2004. Evaluation of current fertilizer practice and soil fertility in vegetable production in the Beijing region. Nutr. Cycl. Agroecosyst. 69:51-58.

Fink, M. and H.C. Scharpf. 1993. N-expert-a decision support system for vegetable fertilization in the field. Acta Hort. 399:67-74.

Goudriaan, J. and H.H. Van Laar. 1994. Modelling potential crop growth processes: Textbook with exercises. Current issues in production ecol- ogy. Kluwer Academic Publishers, Dordrecht, the Netherlands.

Greenwood, D.J. 2001. Modelling N-response of field vegetable crops grown under diverse condition with N ABLE. J. Plant Nutr. 24:1799-1815.

Hartz, H.K., G. Miyao, and R.J. Mullen. 1999. Potassium requirements for maximum yield and fruit quality of processing tomato. J. Amer. Soc. Hort. Sci. 124:199-204.

Hebbar, S.S., B.K. Ramachandrappa, H.V. Nanjappa, and M. Prabhakar. 2004. Studies on NPK drip fertigation in field grown tomato (Lycopersicon esculentim Mill.). Eur. J. Agron. 21:117-127.

Ju, X.T., X.J. Liu, F.S. Zhang, and M. Roelcke. 2004. Nitrogen fertilization, soil nitrate accumulation, and policy recommendations. Ambio 33:300-305.

Li, H.S. 2000. Principles and techniques of plant physiology and biochemistry experiment. Higher Education Press, Beijing, China.

Lin, D., D.F. Huang, and S.P. Wang. 2004. Effects of potassium levels on fruit quality of muskmelon in soilless medium culture. Scientia Hort. 102:53-60.

Lu, R.S. 1999. Chemical analysis method of soil agriculture. China Agricultural Science and Technology Press, Beijing, China.

Marschner, H. and P. Marschner. 2012. Marschner's mineral nutrition of higher plants. Elsevier, London, UK.

Mohammad, F. and U. Naseem. 2006. Effect of K application on leaf carbonic anhydrase and nitrate reductase activities, photo-synthetic characteristics, $\mathrm{NPK}$ and $\mathrm{NO}_{3}{ }^{-}$contents, growth and yield of mustard. Photosynthetica 44:471-474.

Nendel, C. 2009. Evaluation of best management practices for $\mathrm{N}$ fertilisation intraregional field vegetable production with a small-scale simulation model. Eur. J. Agron. 30:110-118.

Oosterhuis, D.M., D.A. Loka, E.M. Kawakami, and W.T. Pettigrew. 2014. The physiology of potassium in crop production. Adv. Agron. 126:203-233.

Rahn, C.R., K. Zhang, R. Lillywhite, C. Ramos, J. Doltra, J.M. De Paz, H. Riley, M. Fink, C. Nendel, K. Thorup-Kristensen, A. Pedersen, F. Piro, A. Venezia, C. Firth, U. Schmutz, F. Rayns, and K. Strohmeyer. 2010. EU-Rotate $\mathrm{N}-\mathrm{a}$ decision support system-to predict environmental and economic consequences of the management of nitrogen fertiliser in crop rotations. Eur. J. Hort. Sci. 75:20-32.

Rahn, C., A. Mead, A. Draycott, R. Lillywhite, and T. Salo. 2001. A sensitivity analysis of the prediction of the nitrogen fertilizer requirement of cauliflower crops using the HRI WELL N computer model. J. Agr. Sci. 137:55-69.

Shao, J.Q. 2010. Quantify the effects of water and nitrogen coupling on the growth of the standard cut chrysanthemum 'Jinba' in solar greenhouse. Nanjing Agric. Univ., China, MS Thesis.

Soto, F., M. Gallardo, C. Giménez, T. Peña-Fleitas, and R.B. Thompson. 2014. Simulation of tomato growth, water and $\mathrm{N}$ dynamics using the EU-Rotate $\mathrm{N}$ model in Mediterranean greenhouses with drip irrigation and fertigation. Agr. Water Mgt. 132:46-59.

Suárez-Rey, E.M., M. Romero-Gámez, C. Giménez, R.B. Thompson, and M. Gallardo. 2016. Use of EU-Rotate $\mathrm{N}$ and CropSyst models to predict yield: Growth and water and $\mathrm{N}$ dynamics of fertigated leafy vegetables in a Mediterranean climate and to determine $\mathrm{N}$ fertilizer requirements. Agr. Syst. 149:150 164.

Wang, X.B., D.X. Cai, W.B. Hoogmoed, U.D. Perdok, and O. Oenema. 2007. Crop residue, manure and fertilizer in dry land maize under reduced tillage in northern China: I grain yields and nutrient use efficiencies. Nutr. Cycl. Agroecosyst. 79:1-16.

Wang, X.J., J.X. Chen, X.Q. Li, Z.S. Wu, Z.S. Liang, M. Wang, and F.H. Gao. 2017. Effects of potassium on muskmelon plant growth and photosynthetic characteristics. Chinese J. Trop. Crops 38:1628-1632.

Xu, R., J. Dai, W. Luo, X. Yin, Y. Li, X. Tai, L. Han, Y. Chen, L. Lin, G. Li, C. Zou, W. Du, and M. Diao. 2010. A photothermal model of leaf area index for greenhouse crops. Agr. For. Meteorol. 150:541-552.

Yang, X.F., G. Li, W.H. Luo, L.L. Chen, S.P. Li, M. Cao, and X.B. Zhang. 2015. Quantifying the relationship between leaf nitrogen content and growth dynamics and yield of muskmelon grown in plastic greenhouse. HortScience 50:1677-1687.

Yuan, C.M., W.H. Luo, X. Tai, S.F. Zhang, L. Jin, Y.S. Chen, C.X. Bu, and G. Xu. 2006. Simulation of dry matter partitioning, yield formation and fruit harvest date of greenhouse muskmelon [in Chinese with English abstract]. Scientia Agricultura Sinica 39:353360.

Zhu, Z.L. and D.L. Chen. 2002. Nitrogen fertilizer use in China-contributions to food production, impacts on the environment and best management strategies. Nutr. Cycl. Agroecosyst. 63: 117-127. 